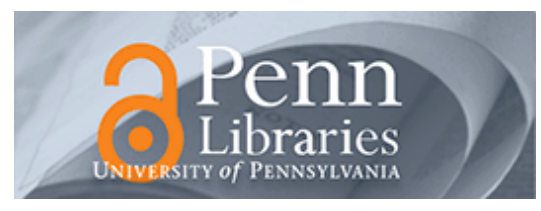

University of Pennsylvania

ScholarlyCommons

Accounting Papers

Wharton Faculty Research

$12-2009$

\title{
Investor Perceptions of Board Performance: Evidence From Uncontested Director Elections
}

Paul E. Fischer

University of Pennsylvania

Jeffery D. Gramlich

Brian P. Miller

Hal D. White

Follow this and additional works at: https://repository.upenn.edu/accounting_papers

Part of the Accounting Commons

\section{Recommended Citation}

Fischer, P. E., Gramlich, J. D., Miller, B. P., \& White, H. D. (2009). Investor Perceptions of Board Performance: Evidence From Uncontested Director Elections. Journal of Accounting and Economics, 48 (2-3), 172-189. http://dx.doi.org/10.1016/j.jacceco.2009.09.002

This paper is posted at ScholarlyCommons. https://repository.upenn.edu/accounting_papers/127

For more information, please contact repository@pobox.upenn.edu. 


\title{
Investor Perceptions of Board Performance: Evidence From Uncontested Director Elections
}

\begin{abstract}
This paper provides evidence that uncontested director elections provide informative polls of investor perceptions regarding board performance. We find that higher (lower) vote approval is associated with lower (higher) stock price reactions to subsequent announcements of management turnovers. In addition, firms with low vote approval are more likely to experience CEO turnover, greater board turnover, lower CEO compensation, fewer and better-received acquisitions, and more and better-received divestitures in the future. These findings hold after controlling for other variables reflecting or determining investor perceptions, suggesting that elections not only inform as a summary statistic, but incrementally inform as well.
\end{abstract}

\section{Keywords}

performance measurement, corporate governance, corporate democracy, director elections

\section{Disciplines}

Accounting 


\title{
Investor Perceptions of Board Performance: Evidence from Uncontested Director Elections
}

\author{
Paul E. Fischer \\ The Smeal College of Business, The Pennsylvania State University \\ E-mail: pef5@psu.edu \\ Phone: (814) 863-3569 \\ Jeffrey D. Gramlich \\ University of Southern Maine School of Business and Copenhagen Business School \\ E-mail: gramlich@maine.edu \\ Phone: (207) 228-8232 \\ Brian P. Miller \\ Kelley School of Business, Indiana University \\ E-mail: bpm@indiana.edu \\ Phone: (812) 855-2606 \\ Hal D. White \\ Ross School of Business, University of Michigan \\ E-mail: halwhite@bus.umich.edu \\ Phone: (734) 647-1966
}

This version: August 2009

We would like to thank Jim Bennett, Scott Bronson, Marcus Caylor, Fabrizio Ferri, David Haushalter, Karen Hennes, Henock Louis, Michelle Lowry, Ric Marshall, Robert Monks, Karl Muller, Monica Neamtiu, Robert Parrino (referee), Richard Sias, Bert Smoluk, Ross Watts (editor), Jerry Zimmerman, and workshop participants at the University of Michigan, the University of Southern Maine, and the 2007 AAA Annual Meeting for helpful comments and suggestions. We thank Diane Del Guercio, Laura Wallis, and Tracie Woidtke for data on vote-no campaigns and Stuart Gillan, Jay Hartzell, and Robert Parrino for data on CEO compensation contracts. The authors gratefully acknowledge Chris Hennes for assisting with data extraction, Mike Kusuma and Joel Miller for assistance with data collection, and Andy Leone and The Corporate Library for providing data. This paper was previously titled "Uncontested Director Election Results and Board Performance." 


\title{
Investor Perceptions of Board Performance: Evidence from Uncontested Director Elections
}

\begin{abstract}
This paper provides evidence that uncontested director elections provide informative polls of investor perceptions regarding board performance. We find that higher (lower) vote approval is associated with lower (higher) stock price reactions to subsequent announcements of management turnovers. In addition, firms with low vote approval are more likely to experience CEO turnover, greater board turnover, lower CEO compensation, fewer and better received acquisitions, and more and better received divestitures in the future. These findings hold after controlling for other variables reflecting or determining investor perceptions, suggesting that elections not only inform as a summary statistic, but incrementally inform as well.
\end{abstract}




\section{Introduction}

Every year the vast majority of publicly traded firms' shareholders vote to approve members of the board of directors in uncontested elections (i.e., elections not involving proxy fights or vote-no campaigns). The lack of contested elections, coupled with the widespread use of plurality voting rules, implies director nominees almost always prevail. Consequently, commentators claim that director elections are meaningless charades of shareholder democracy (Morgenson, 2006; Monks and Minow, 2004). ${ }^{1}$ We conjecture, however, that uncontested elections serve as meaningful polls reflecting investor perceptions of board performance. The objective of this study is to empirically test this conjecture.

We construct approval measures using director vote tallies for a sample of S\&P 500 firms from 2000-2004, and find evidence consistent with these measures reflecting investor perceptions of board performance. In particular, we examine the relation between the approval measures and the stock price response to a change in the most focal member of the board, the CEO. We find that higher (lower) approval is associated with lower (higher) stock price reactions to subsequent announcements of management turnovers. We also show that the approval measures predict uncertain future events expected to be associated with board performance. Specifically, we find that firms with low board approval are associated with a higher likelihood of CEO turnover, greater board turnover, lower CEO compensation, fewer and better received acquisitions, and more and better received divestitures subsequent to the vote.

We also assess whether the approval measures are incrementally informative to traditional metrics of board performance, such as stock returns and return on assets. We conjecture that a vote tally, which in principle pertains solely to board performance, is less likely to be contaminated by sources of noise inherent to equity market and financial metrics, such as commodity price movements and other economic shocks that are independent of management

1 Under plurality voting rules, the director nominee who receives the greatest number of affirmative votes is elected to fill an open board seat (i.e., a majority vote is not required). Consequently, when a slate of nominees put forward by the board runs unopposed, each nominee can be elected with a single affirmative vote. 
decisions. Consistent with our conjecture, the information content in the vote approval measures is largely unaffected by the inclusion of controls for traditional metrics of board performance. Hence, the vote approval metrics are uniquely meaningful measures of board performance.

This study contributes to the existing literature by showing that uncontested votes reflect investor perceptions of board performance, despite a number of reasons suggesting otherwise. First, shareholders do not always vote diligently, either because the outcome is preordained or because their vote has an immaterial impact on the outcome (Downs, 1957). For example, shareholders owning "street name" shares (i.e., shares held by a broker) often do not provide the broker with voting instructions, which permits the broker to vote the shares. ${ }^{2}$ Also, some investors are alleged to follow the "Wall Street rule," whereby they vote in favor of the slate proposed by the board, and only vote against the board by selling their shares (Lowenstein, 1988; Parrino, Sias, and Starks, 2002). Second, even if some shareholders do vote diligently, the votes they cast could be too few in number for their perceptions to be detectible. Finally, because only shareholders of record can vote, the votes of shareholders who do vote diligently do not necessarily reflect broader investor perceptions (Fischer, 2007). Our findings suggest uncontested votes do reflect investor perceptions in spite of these countervailing forces.

The results of our analyses should also be useful to researchers, regulators, and governance commentators. For instance, our approval measure can be used to complement existing governance measures, such as the Gompers, Ishii, and Metrick (2003) index, which focus primarily on governance structures (e.g., existence of classified board or board size) as opposed to the performance of the individuals operating within those structures. Further, the findings inform regulators and governance commentators debating recent calls to strengthen shareholder democracy (see Bebchuk, 2007), such as proposals to require majority voting requirements.

2 Broker votes are allowed only for routine matters, which includes uncontested director elections. Typically, broker votes are cast in favor of the proposed slate. A primary rationale for allowing broker votes is that they help ensure that a quorum is reached, which is necessary for the vote to transpire. See Bethel and Gillan (2002). 
The rest of the paper is organized as follows. In the next section, we discuss related literature. Section 3 provides information related to the sample and descriptive statistics. Our primary results are reported in sections 4 and 5. Section 6 describes the results of the supplementary tests, and concluding comments are provided in section 7.

\section{Related Literature}

Our study contributes to several streams of literature, starting with shareholder activism literature, which focuses on contested shareholder votes involving proxy fights and vote-no campaigns. ${ }^{3}$ Contested elections are rare because the dissatisfied investors who initiate them incur significant costs. We focus instead on uncontested elections because they allow us to assess whether the usual voting process elicits information regarding investor perceptions. Further, we examine the information conveyed by the vote tally itself, whereas the contested vote literature focuses primarily on the information conveyed by the existence of a contested vote. ${ }^{4}$

Another stream of literature assesses whether institutional investors vote with their feet. Parrino et al. (2002) find that in periods prior to forced turnovers, institutional investors vote against management by selling their holdings. We complement their findings by providing evidence that similar investor perceptions are reflected in the vote tallies. That is, in addition to the Parrino et al. finding that institutional investors vote with their feet, we find that some investors express their preferences via the vote.

Our study also relates to the management performance and governance literatures. We contribute to the literature on non-financial management performance measures by providing a metric of board member performance that is relatively uncontaminated by exogenous sources of

3 Examples of research on proxy fights include Dodd and Warner (1983), DeAngelo (1988), Pound (1988), Collins and DeAngelo (1990), Denis and Denis (1995), and Mulherin and Poulsen (1998). A concurrent paper by Del Guercio et al. (2008) investigates vote-no campaigns. Studies of other forms of shareholder activism include Smith (1996) and Carleton, Nelson, and Weisbach (1998).

4 A concurrent paper, Cai, Garner, and Walkling (2009), also studies shareholder votes for directorships using a sample of both contested and uncontested ISS director voting data from 2003-2005. Cai et al. examine firm- and director-level variables associated with the election vote whereas our study attempts to validate the use of the vote to proxy as a summary measure of investor perceptions. Also, in supplementary analyses, we decompose the approval measure into numerator and denominator effects in order to better understand the factors driving the approval measure's information content. 
noise afflicting stock returns and financial measures of performance. ${ }^{5}$ The approval measure also can be used to complement existing governance measures that focus primarily on governance structures as opposed to the performance of the individuals operating within those structures. ${ }^{6}$

In addition, our work links to the broad CEO turnover literature, which generally seeks to identify factors that determine or predict CEO turnover. ${ }^{7}$ We use a CEO turnover prediction model to test the joint hypothesis that the vote reflects investor perceptions of the board's performance, and that those perceptions are associated with CEO retention. Thus, CEO turnover prediction is not the primary aim.

\section{Sample and descriptive statistics}

\subsection{Sample selection}

Our sample consists of the Standard \& Poor's 500 list at January 1, 2000, representing 2,500 potential firm-year observations across the five years ending December 31, 2004. Because institutional investment policies often mandate holdings of S\&P 500 firms (e.g., an S\&P 500 index fund), S\&P 500 firms are more likely than non-S\&P 500 firms to be heavily owned by investors who are unable to vote with their feet. Therefore, the vote results for S\&P 500 firms should be more reflective of broader investor perceptions.

We hand-collect more than 10,000 individual director votes over the period 2000 to 2003, and collect an additional 2,250 individual director votes from the Institutional Shareholder Voting Analytics (ISVA) database for 2004. ${ }^{8}$ Voting outcomes are obtained from Item 4 of the

5 See Ittner and Larcker (2001) for a summary of non-financial performance measure literature in several contexts.

6 Note that successful governance is highly contingent on management's stewardship, regardless of the structures in place. For example, a board with a large percentage of insiders is typically thought to have 'bad' governance; however, the performance of the firm actually rests with how well the board operates the firm, not the degree to which some of the board members are insiders. Examples of studies that use structural indicators of governance include Shivdasani (1993), Core, Holthausen, and Larcker (1999), Klein (2002), Andersen, Mansi, and Reeb. (2004), Ashbaugh-Skaife, Collins, and LaFond. (2006), and Larcker, Richardson, and Tuna (2007).

7 See, for example, Warner, Watts, and Wruck (1988), Morck, Schleifer, and Vishny (1989), Parrino (1997), DeFond and Park (1999), Huson, Parrino, and Starks (2001), Goyal and Park (2002), Engel, Hayes, and Wang (2003), Farrell and Whidbee (2003) and Balsam and Miharjo (2007).

${ }^{8}$ The ISVA database started in 2003 and covers the Russell 3000 company meetings. However, we had already hand-collected this data before the database was available. To ensure there were no material differences between the hand-collected sample and the ISVA data, we correlated the data for the overlapping period, i.e., 2003, and found approximately $99 \%$ correlation. 
first 10-Q filing reported on the SEC's EDGAR database after the annual meeting. Not all firms disclose detailed voting outcomes, however, which limits the size of our potential sample. Further, when a firm ceases to exist during the 2000 to 2004 period, our data set includes only the votes up until the firm's termination, causing survivorship bias because we do not replace firms ceasing to exist. Hence, the generality of our findings could be limited.

As described in Table 1, after eliminating firms in the utility sector, firms missing board approval data, and observations with missing data on CRSP, Compustat, or Thomson Financial, the sample consists of 1,564 annual board elections. Next we eliminate votes associated with contested elections, which are defined as votes occurring during a vote-no campaign or a proxy fight. Del Guercio et al. (2008) provide us with a list of the vote-no campaigns for the years 2000 to 2003. Their sample involved searches of Lexis-Nexis, Factiva, The Wall Street Journal Index, and issues of the IRRC Corporate Governance Bulletin. We use the same keyword searches to replicate their search process for 2004, although we search EBSCO and Factiva, which parallel the data sources they search. Further, we search the IRRC Corporate Governance Bulletin and Google in an effort to identify all cases where there was a concerted effort to convince other investors to vote against specific directors. ${ }^{9}$ To identify proxy contests during the 2000 to 2004 period, we search the Proxy Contests and other Major Activist Events section of the yearly Georgeson Shareholder Annual Meeting Season Wrap-Up Report.

Finally, we eliminate 15 observations related to firms having dual-class shares with each class selecting a subset of directors. These observations are eliminated because the vote outcomes cannot be summarized with our board approval measure. Together, these restrictions result in a sample of 1,497 annual election observations with available data for the board approval analyses, and a sample of 827 observations for the CEO approval analyses.

\footnotetext{
9 Consistent with Del Guercio et al. (2008), we do not classify elections as vote-no campaigns when institutional investors, such as CalPERS or ISS, merely mention that they intend to vote against a specific board member. Excluding such elections would eliminate nearly all of the firms in our sample, as in the 2004 proxy season when "CalPERS recommended that shareholders withhold votes for directors at 2,700 companies, or $90 \%$ of the firms that CalPERS invests in" (Iwata, 2004).
} 


\subsection{Approval measures}

Under the current corporate electoral system, shareholders cannot directly cast a 'no' vote on director nominees. Rather, SEC Rule $14 \mathrm{a}-4$ (b) requires a company to provide shareholders with the option to cast their share votes to either support or withhold support for a director nominee. Our objective is to use the uncontested vote tallies to derive a summary statistic of board performance for each firm in each year. Using the election results disclosed to investors in the 10-Q filing after the annual meeting, we compute the percentage of affirmative votes for each director nominee:

$$
\frac{\text { votes for }}{\text { votes for }+ \text { votes withheld }}
$$

where the denominator equals the total votes cast.

The primary summary approval measure used for our analysis, board approval (BRD_APPR), is the median percentage of affirmative votes for each slate of nominees. We use the median, as opposed to the mean, to avoid capturing shareholder dissatisfaction with a specific board member for a matter unrelated to overall board performance. We conjecture $B R D \_A P P R$ reflects investor perceptions of board performance based on the assumption that shareholder dissatisfaction with the board is manifested in more withheld votes. This conjecture is supported by the observation that some active investors withhold their votes from the entire slate of directors when they are dissatisfied with current management. For instance, CalSTRS's investor protector standards include the following summary of their voting practices: "Votes may be withheld [for the entire slate] when it appears that the existing board has been remiss in the performance of its oversight responsibilities" (CalSTRS, 2003).

We note that $B R D \_A P P R$ is impacted by vote turnout indirectly because the denominator is the number of votes cast. If turnout varies significantly with investor perceptions, turnout could alter the informativeness of the approval statistic. Although this issue is directly addressed later in the paper, at this point it is worth noting that the percentage of outstanding shares voted (i.e., turnout) is, on average, quite high within our sample, with a mean of $87 \%$ (median of $87 \%$ ). The 
high turnout is partially attributable to institutional shareholders who are required to vote to satisfy their fiduciary responsibilities and who comprise a large segment of S\&P 500 shareholders. ${ }^{10}$ The high turnout also can be partially attributed to broker votes, which are votes made by brokers of 'street name' shares when the beneficial owners have not conveyed their voting preferences.

We also consider a more focused measure of approval, CEO approval (CEO_APPR), which is the percentage of affirmative votes for the CEO when the CEO is on the slate of nominees in a given year. CEO_APPR is not available each year due to staggered elections of board members, which substantially reduces the number of available $C E O \_A P P R$ observations. If an individual director's vote tally reflects investor perceptions of only that director, we expect tests using CEO_APPR and BRD_APPR to yield different results. Similar results, however, would validate the use of the $B R D \_A P P R$ statistic as a relevant performance metric for the management team.

\subsection{Descriptive data}

Panels $\mathrm{A}$ and $\mathrm{B}$ of Table 2 summarize the distributions of $B R D \_A P P R$ and $C E O \_A P P R$ by year and across the entire sample period. The vast majority of $A P P R$ values exceed $95 \%$ and nearly all are in the range between $85 \%$ and $100 \%$. This suggests that a seemingly favorable rating, say $80 \%$, is less favorable when taken in the context of typical approval ratings.

Table 2 also suggests that mean and median values of approval have declined since 2000. This reduction in approval could be attributed to a greater sense of shareholder activism and/or general investor disgruntlement due to the declining stock market and corporate scandals. Regardless of the cause, an approval rating of $85 \%$ in the later years could reflect investor perceptions a bit differently than a rating of $85 \%$ in the earlier years. To control for year effects, we include year fixed effects when continuous measures of board and CEO approval are employed. Additionally, we create annual quintiles for board approval (i.e.,

\footnotetext{
${ }^{10}$ Based on Thompson Financial 13(f) institutional shareholder data, institutions held, on average, 68\% (median $70 \%$ ) of the common shares of the firms in our sample.
} 
QUINT_BRD_APPR) and CEO approval (i.e., QUINT_CEO_APPR). Employing an ordinal ranking also limits the impact of individual observations falling in the extreme lower tail of the skewed vote distribution.

Table 3 provides correlations of the various approval measures with each other as well as with other metrics reflecting board performance. The correlation between any board approval measure and the analogous CEO approval measure is about $80 \%$. These positive correlations suggest common factors drive both board and CEO approval metrics, consistent with investors assessing the governing team as a whole. We also examine the correlations of various alternative director approval subgroups to validate our notion that the board is generally viewed as one large management team, as opposed to individuals, in terms of performance evaluation. In untabulated results, we find similarly high correlations between approval for a board member selected at random, approval for the second-lowest-rated director, approval for the fourth-lowest-rated director, mean (as opposed to median) director approval, and mean and median approval for nonCEO board members. This strongly suggests that board members tend to receive similar approval ratings.

We next consider correlations between the approval measures and other metrics reflecting board performance: industry-adjusted return on assets, industry-adjusted stock returns, and changes in institutional ownership. We expect the approval measures to be positively related to industry-adjusted stock returns and industry-adjusted return on assets leading up to the vote, since board performance is linked to firm performance. We do not have a directional prediction regarding the relation between the change in institutional ownership and the approval measures. On one hand, we expect a positive relation if institutional investor satisfaction is shared by investors holding shares at the vote date; that is, institutions decrease (increase) holdings as other shareholders in the firm vote more negatively (positively). On the other hand, we expect a 
negative relation if institutional investor satisfaction is not shared with the non-institutional investors. Thus, it remains an empirical question whether the votes made by investors who vote their shares concur with the votes made by institutional investors who vote with their feet.

The time horizon over which performance assessments are made by investors is unclear, so we consider industry-adjusted stock returns and return on assets for a firm over three years. ${ }^{11}$ That is, we calculate $R E T_{t}, R E T_{t-1}$, and $R E T_{t-2}$ as the industry-adjusted 12-month return for each of the three years immediately preceding the annual meeting when the vote takes place. We use industry-adjusted returns as opposed to market-adjusted returns, because industry-adjusted returns eliminate both market-wide and industry-wide shocks that are beyond the control of the board. Similarly, we calculate $R O A_{t}, R O A_{t-1}$ and $R O A_{t-2}$ as the four-quarter industry-adjusted return on assets for each of the three years immediately preceding the annual meeting when the shareholder vote takes place. The inclusion of the performance variables for each year in the regressions controls for trends and/or changes in firm performance across those years as well. ${ }^{12}$ We industry-adjust the $R E T$ and $R O A$ values by subtracting median industry values based on the Fama and French (1997) 48 industry sectors.

Table 3 indicates a significant positive association between our approval measures and the various returns on assets and stock returns, which is consistent with the approval measures reflecting perceptions of board performance. These correlations are consistent with previous studies of contested election tallies, which find similar relations using votes cast for various shareholder proposals (Gillan and Starks, 2000; Ferri, Markarian, and Sandino, 2004; and Ferri, Ertimur, and Stubben, 2008) and votes cast during vote-no campaigns (Del Guercio et al., 2008). Our analysis adds to this research by providing broader cross-sectional representation and by

\footnotetext{
${ }^{11}$ In the CEO turnover literature, Warner et al. (1988) use up to three-year stock return horizons as the relevant performance measure while Huson et al. (2001) employ both two-year return and one-year ROA horizons and Engel et al. (2003) employ one-year return and ROA horizons.

${ }^{12}$ We also run all the analyses in the paper using changes in ROA for the previous 3 years and the results are unaffected.
} 
considering votes in which no outside parties actively promote a position, as in the case of shareholder proposals and vote-no campaigns.

CHG_INST_OWN is the change in institutional holdings over the four quarters ending immediately preceding the annual meeting. We determine the number of outstanding shares owned by 13(f) institutions as a percentage of the total number of shares outstanding as reported for the same quarter by Compustat, after adjusting for stock split differences. The correlations in Table 3 reveal no significant correlation between $C H G_{-} I N S T_{-} O W N$ and any of the approval measures.

\section{Stock price response to turnover announcements}

Although the correlations identified in Table 3 suggest that vote tallies capture investor perceptions regarding board performance, these correlations could merely indicate that approval reflects shareholder perceptions of past stock price or financial performance, regardless of whether the performance is attributed to the board. Hence, we undertake additional analyses to link our approval measures with the capital market response to a salient event involving the board - CEO turnover. We focus on CEO turnover announcements, as opposed to board turnover announcements, because a CEO turnover typically represents a more substantive economic event with an identifiable announcement date.

The board plays a pivotal role in monitoring the managers of a public corporation, and removing a CEO is potentially the most important monitoring decision a board will make (Fama and Jensen, 1983; Huson et al., 2001). As a consequence, the presence of a poorly (well) perceived CEO is perceived as a failure (success) of the board, where the degree of failure (success) is associated with how poorly (well) the CEO is perceived to be performing. Assuming $B R D \_A P P R$ reflects these perceptions, we expect investors to react more (less) favorably to the

announcement of a CEO departure if $B R D \_A P P R$ is relatively low (high). We also expect a similar relation between $C E O \_A P P R$ and investor reactions to CEO departures. Note that if an individual board member vote tally relates only to the perceptions of that individual board member, only the expected relation for $C E O_{-} A P P R$ will hold. 
We identify CEO turnovers using year-to-year changes within the CEO name variable of the ExecuComp database. We then search ProQuest and Google for press announcements to identify the initial turnover announcement date. Using this process, we identify 185 CEO turnovers in our sample occurring within the year subsequent to annual meetings where the votes are tallied. Of these 185 turnovers, we exclude 18 associated with concurrent merger announcements or missing data. Of the remaining turnovers, we have board approval for all 167 turnovers and CEO approval for 82 turnovers.

We measure the stock price response to the turnover announcement as the five-day $(-3,+1)$ cumulative abnormal stock return (CAR) surrounding the CEO turnover announcement. We apply the market model to estimate firm-specific CARs using CRSP-population data based upon a 255-day period ending 46 days before the announcement date. Panel A of Table 4 presents regression results of five-day $\mathrm{CEO}$ turnover announcement CARs, CEO_CAR, on the four approval measures in the following univariate regression, referred to as the "Short Model":

$$
C E O \_C A R_{i, t+1}=\beta_{0}+\beta_{1} * A P P R_{i, t}+\varepsilon_{i, t},
$$

where $A P P R$ is the relevant approval measure (i.e., $Q U I N T_{-} B R D_{-} A P P R, B R D_{-} A P P R$ QUINT_CEO_APPR, or CEO_APPR) for the vote outcome associated with the firm's annual meeting most closely preceding the turnover announcement. If the approval measure reflects investor perceptions, we should observe a negative coefficient on the relevant approval measure. Panel A of Table 4 also reports regression results for a "Long Model" controlling for other readily accessible performance statistics available at the time of the vote, which prior research has shown to reflect management's performance: ${ }^{13}$

$$
C E O{ }_{-} C A R_{i, t+1}=\beta_{0}+\beta_{1} * A P P R_{i, t}+C O N T R O L S_{i}+\varepsilon_{i, t}
$$

\footnotetext{
13 Warner et al. (1988) and Weisbach (1988) find an association between past (market-adjusted) stock returns and "top management changes." More recent studies assessing turnover prediction also observe an association between past measures of financial performance, such as industry-adjusted ROA, and CEO turnover (see, for example, Huson et al., 2001 and Engel et al., 2003). Parrino et al. (2002) and Del Guercio et al. (2008) find a relationship between changes in institutional holdings and subsequent $\mathrm{CEO}$ turnover.
} 
where CONTROLS $S_{i}$ represents the incorporation of the following statistics into the regression: $R E T_{i, t}, R E T_{i, t-1}, R E T_{i, t-2}, R O A_{i, t}, R O A_{i, t-1}, R O A_{i, t-2}$, and $C H G_{-} I N S T_{-} O W N_{i, t .}$ If the approval measures are not subsumed by the information contained in these other statistics, we expect to observe significantly negative coefficients on the approval measures. Following Froot (1989), we use Huber (1967) and White (1980) sandwich estimates of variances to adjust the standard errors for possible correlation in errors among observations involving the same firm (i.e., we cluster by firm) for both models and include year dummies when examining the continuous approval measures. Year dummies are not included if quintiled approval measures are used because creating quintiles within each year controls for year fixed effects. A similar approach is employed in subsequent analyses as well.

The results for the Short Models indicate that both QUINT_BRD_APPR and QUINT_CEO_APPR have the predicted sign and are statistically significant at the $5 \%$ level. The results for $B R D \_A P P R$ are significant at the $1 \%$ level, while the results for $C E O \_A P P R$ are significant at the $10 \%$ level. Moreover, the relationship between approval and the CEO departure return appears to be robust to the inclusion of alternative performance metrics. ${ }^{14}$

An implicit assumption in the framing and interpretation of tests summarized in Panel A of Table 4 is that investors' expectations related to the fit (e.g., ability and/or strategic direction) of the incoming CEO are different from that of the incumbent. That is, the return at the turnover announcement date is a function not only of attributes regarding the departing CEO, but also of the attributes of the CEO who replaces, or is expected to replace, the departing CEO. Clearly, the replacement of a poorly perceived CEO with a "clone" would not warrant a positive market reaction because the replacement would not reflect a change from the status quo. In fact, it may even result in a negative reaction as investors become less hopeful for change. Similarly, the

\footnotetext{
${ }^{14}$ To ensure that neither the low or high approval group is the sole driver of these results, we further examine the extreme approval quintiles to assess whether the expected association continues to hold for both. In untabulated results, we find that firms with the lowest approval receive significantly positive market reactions around CEO departure announcements and firms with the highest approval receive significantly negative market reactions around CEO departure announcements, which suggests that neither group individually drives the result.
} 
departure of a well-regarded CEO warrants a negative reaction to the degree that if investors view the successor as a person who will change the favorable status quo.

Consistent with the above line of reasoning, Borokhovich, Parrino, and Tarpani (1996) find that returns around forced CEO turnover announcements are positive (negative) when an outsider (insider) replaces a CEO. The story underlying this finding is that an insider replacement is less likely to bring about a substantial change from the status quo associated with the predecessor CEO. That is, the insider/outsider partition is essentially a proxy for whether the successor is a change agent. If the vote approval metrics reflect investor satisfaction with the status quo, the findings in Borokhovich et al. (1996) lead us to predict that the stock price response to an insider replacement will be higher (lower) than that of an outsider replacement when the vote approval metric is higher (lower).

In order to test this prediction, we search Factiva and Google to determine whether the CEO replacement was an insider or outsider. Of the 167 CEO departure announcements in Panel A, 116 named an insider replacement, 16 named an outsider, and 35 mentioned that a replacement search would be conducted and/or no indication was given as to the replacement. Almost $88 \%$ (i.e., 31/35) of those that do not mention a replacement at the departure announcement eventually hire an outsider. Since we are trying to capture the market's expectation of change, we code this group as an outside replacement. Similar results are obtained when we assume a strong form of rational expectations by coding Insider as one if an insider ultimately replaces the CEO, and zero otherwise.

We modify equations (1) and (2) with the addition of a dummy variable INSIDER, which equals one if there is an insider replacement and zero otherwise, and an interactive term, $A P P R^{*} I N S I D E R$. If our prediction is correct, the approval measures should load negatively (as in Panel A), since this coefficient now represents the effect of approval given an outside replacement (i.e., our proxy for change). We expect a positive coefficient on the interactive term to indicate the effect is mitigated when there is an insider replacement because insiders are more likely to maintain the status quo. 
Panel B of Table 4 reports the results for the Short and Long Model augmented to include INSIDER and APPR*INSIDER. As in Panel A, the coefficients on the approval measures are negative, and statistically significant, with larger t-statistics, for three of the four measures. QUINT_BRD_APPR is still negative, but no longer statistically significant at conventional levels. With the exception of the regressions employing $Q U I N T_{-} B R D_{-} A P P R$, the coefficients on $A P P R^{*} I N S I D E R$ are positive and statistically significant at conventional levels in the Short Models. Furthermore, the coefficients on $A P P R^{*} I N S I D E R$ have magnitudes similar to the $A P P R$ measures, indicating that the stock price reaction to a CEO departure announcement is largely mitigated when firms replace the CEO with a protégé. When other performance measures are incorporated, the statistical significance of the coefficients on APPR*INSIDER is generally diminished, although the signs are still positive. Overall, this combined evidence suggests that vote tallies reflect market perceptions of performance. In addition, the market response to a turnover is a function of both the perceptions of the departing CEO and the replacement CEO.

\section{Approval measures as predictors of future events}

Beyond reflecting perceptions at a point in time, a more useful poll predicts the outcome of an uncertain future event. The next set of tests, which reflect this point of view, relate approval measures to significant future corporate events likely to be associated with perceptions of board performance. In particular, if the approval measures capture investor perceptions of board performance, we expect to find that lower vote approval will be associated with higher probability of forced CEO turnover, higher probability of outside replacement CEOs, and reductions in excess CEO compensation. We also expect that firms with lower vote approval will make fewer acquisitions in the future, and that the acquisitions that are made will garner more favorable perception in the marketplace. In a similar vein, we expect firms with lower vote approval will have both more and better-received divestitures. It is important to note that the tests of these hypothesized associations are not tests of whether the votes, or the perceptions reflected in the votes, directly cause the actions to occur. Instead, they are merely joint tests of whether 
perceptions of performance are reflected in the vote, and whether these perceptions are associated with subsequent events of interest.

\subsection{CEO turnover}

The CEO turnover literature conjectures a poorly performing CEO is more likely to be forced out, and the findings in that literature relating measures of performance (i.e., stock price, financial, and change in institutional ownership) to turnover are consistent with this conjecture. (e.g., Warner et al., 1988; Weisbach, 1988; Parrino et al., 2002.) If the approval measures constructed from the vote tallies reflect perceptions of management performance, we also expect low approval measures to be associated with a greater probability of forced CEO turnover. Further, if the noise in the approval measures differs from the noise in the other performance measures, we expect the approval measures to have predictive value even after controlling for the other measures.

To test whether a CEO is more likely to be forced out when vote tallies are less favorable, we identify all CEO turnovers within the sample of firms and then use the methodology employed by Parrino (1997) to identify just the forced turnovers. We classify a turnover as forced if there is a news article or press release in the ProQuest database stating the CEO was fired, forced out, or departed due to unspecified policy differences. Turnovers not classified as forced by the previous criteria are still classified as forced if the CEO was under age 60 at the most recent shareholder meeting, and either (1) there is no article attributing the CEO departure to death, health concerns, or the CEO accepting a different position within the firm or with another firm, or (2) an article reported an announcement of the CEO's retirement plans and the announcement is not at least six months prior to the effective date of the retirement. For turnovers classified as forced because criterion (2) is satisfied, we further investigate whether (a) the CEO took a comparable position elsewhere or (b) subsequent articles identified a personal or business reason for the departure not relating to activities at the firm in question. If either (a) or (b) is satisfied, the turnover is reclassified as unforced. Employing this classification process, our sample contains 55 forced turnovers. For the subsample where $C E O \_A P P R$ is available, there are 30 forced turnovers. 
In order to test the joint hypothesis that low vote approval is positively associated with forced CEO turnovers, we run the following logit regression, which predicts the probability of a forced CEO turnover:

$$
C E O \_T U R N_{i, t+1}=\beta_{0}+\beta_{1} * A P P R_{i, t}+\beta_{2} * A G E_{i, t}+C O N T R O L S_{i}+\varepsilon_{i, t},
$$

where CEO_TURN $N_{i, t}$ equals 0 if no forced turnover for firm $i$ occurs (i.e., there is no turnover or an unforced turnover) in the period from the annual meeting at date $t$ up to and including the next annual meeting date and equals 1 if a forced turnover occurs within the window; $A P P R$ is the relevant approval measure, i.e., $Q U I N T \_B R D \_A P P R, B R D \_A P P R, B Q 1, Q U I N T \_C E O \_A P P R$, $C E O \_A P P R$, or $C Q 1$, where $B Q 1$ (CQ1) is an indicator variable that equals one if the board (CEO) approval is in the bottom quintile, and zero otherwise; $A G E$ is the age of the CEO on the annual meeting date, which is obtained from The Corporate Library Governance database if available and the Hoover's database otherwise; and CONTROLS reflects the inclusion of other measures reflecting performance, i.e., $R E T_{t}, R E T_{t-1}, R E T_{t-2}, R O A_{t}, R O A_{t-1}, R O A_{t-2}$, and CHG_INST_OWN .

Panel A of Table 5 reports results consistent with the hypothesized association. Regardless of the approval measure used, the estimated sign is in the predicted direction at the $1 \%$ level, with the exception of QUINT_BRD_APPR and CQ1, which are both significant at the 5\% level. To provide some perspective regarding the economic magnitude of these findings, consider, for example, the regression involving the approval measure $Q U I N T \_B R D \_A P P R$. Assuming all the variables with the exception of $Q U I N T \_B R D \_A P P R$ are set to their mean values, the estimated probability of a forced CEO turnover for $B R D_{-} A P P R$ measures in the first (i.e., lowest) to fifth (i.e., highest) quintiles are $5.1 \%, 4.0 \%, 3.1 \%, 2.4 \%$, and $1.9 \%$, respectively. ${ }^{15}$ Although the probability of forced turnover is relatively small across all quintiles, the percentage change in probabilities across quintiles is substantial. For example, a CEO in the lowest quintile of

\footnotetext{
${ }^{15}$ The probability of a forced turnover in the logit model is $1 /\left(1+\exp \left[-\beta_{0}-\beta_{1}{ }^{*} Q U I N T_{-} B R D \_A P P R-\beta_{2} * A G E-\right.\right.$ CONTROLS]).
} 
$B R D \_A P P R$ is more than two and one-half times as likely to suffer a forced turnover than a CEO in the highest quintile.

\subsection{CEO turnover with outside replacement}

Our finding that a CEO is more likely to be forced out when approval measures are lower is consistent with a forced turnover leading to a change in an unfavorably viewed status quo. The replacement of a CEO with his protégé, however, would most likely lower the probability of change in the status quo. Hence, in Panel B of Table 5 we consider an event that is even more likely to suggest a change - a forced turnover coupled with an outsider replacement. Similar to Panel A, we find that the probability of a forced turnover replaced with an outsider is more likely when there is low approval. Regardless of the approval measure used, the estimated sign is in the predicted direction at the $1 \%$ level, with the exception of $Q U I N T \_C E O \_A P P R$, which is significant at the $5 \%$ level.

For perspective, we again evaluate the probability of a forced turnover where an outsider replaces the CEO using the mean values for the other variables previously provided. The

resulting probabilities of forced outside replacement in the first (i.e., lowest) to fifth (i.e., highest) quintiles of board approval are 3.1\%, 2.0\%, 1.3\%, 0.9\%, and 0.6\%, respectively. Similar to the case of forced turnover, the probability of forced turnover with outside replacement is relatively small across all quintiles, but the percentage change in probabilities across quintiles is substantial. For example, a CEO in the lowest quintile of $B R D \_A P P R$ is more than five times as likely to suffer a forced turnover with outside replacement than a CEO in the highest quintile.

In untabulated results, we find a similar negative relationship between approval and the likelihood of a forced CEO turnover when an insider replaces the CEO, but none of the approval measures are significant at conventional levels. Overall, these findings suggest that lower shareholder approval is associated with higher likelihood of outsider, as opposed to insider, replacement after a CEO is forced out.

\subsection{Board turnover}


In addition to removing the $\mathrm{CEO}$, the management team can be altered by removing and/or replacing directors. To identify director turnover, we use data from the IRRC Director Database and The Corporate Library. We calculate board turnover, BRD_TURN, as the change in the number of board members divided by the number of board seats up for election. We have scaled the change in the number of board members by the board seats up for election because, a priori, we believe that individuals are unlikely to resign prior to the completion of their term due to the psychic or reputation costs associated with an early departure.

We run the following OLS regression to test the relation between vote approval and board turnover:

$$
\text { BRD_TURN } N_{i, t+1}=\beta_{0}+\beta_{1} * A P P R_{i, t}+C O N T R O L S_{i,}+\varepsilon_{i, t},
$$

where $B R D_{-} T U R N_{t^{+}}$is the board turnover for the period from the annual meeting at date $t$ up to and including the next annual meeting date, $A P P R$ is the relevant measure of approval, and CONTROLS are other measures of performance based upon stock returns, return on assets, or changes in institutional ownership. We expect a negative relationship between board approval and board turnover. The results for the full sample of firms where director turnover is available are reported in the first three columns of Table 6 . The coefficients on all approval measures are statistically significant at the $5 \%$ or better level in the predicted direction, indicating that higher (lower) board approval is associated with lower (higher) board turnover in the following year.

Findings in Hermalin and Weisbach (1988) suggest the introduction of a new outside CEO is likely to be associated with broader board shake-ups. To ascertain whether CEO turnovers with outside replacements drive the board turnover results reported in Table 6, we eliminate all observations with outside CEO successions from our sample. The results are reported in columns 4-6 of Table 6 and appear robust to this exclusion. ${ }^{16}$ These findings suggest board shake-ups

\footnotetext{
${ }^{16}$ In untabulated results, we also eliminate all CEO turnovers to determine whether board turnover is associated with CEO turnover in general. The results are qualitatively similar to those reported in columns 4-6 and still significant at conventional levels, albeit slightly weaker.
} 
occur when perceptions of board performance are unfavorable, independent of whether an outsider replaces the CEO.

\subsection{CEO compensation}

In addition to changes in management structure, we hypothesize vote approval is positively associated with a CEO's future compensation. We expect this association for two non-mutually exclusive reasons. First, CEO compensation has been associated with past performance in prior literature, which suggests it should be associated with vote approval if vote approval more broadly reflects management performance (see, for example, Murphy, 1985; Lambert and Larcker, 1987). Second, prior literature regarding press coverage and board decisions has suggested boards could respond to perceptions of their performance in negotiating executive compensation (Core, Guay, and Larcker, 2008). ${ }^{17}$

We compute an excess compensation metric and then assess whether subsequent excess CEO compensation is positively related to the approval measure. ${ }^{18}$ Note the term "excess" need not imply compensation is suboptimal. Excess compensation is the residual from a compensation model incorporating various economic determinants of compensation (i.e., performance metrics, firm size, and CEO tenure). The residual could be due to suboptimal compensation decisions and/or omitted performance metrics in the model.

The excess compensation metric is derived following the approach employed by Core, Guay, and Larcker (2008). Accordingly, we use the following model to estimate expected compensation:

${ }^{17}$ Other studies have considered how perceptions of board performance in the press might influence governance decisions. For example, Louis, Joe, and Robinson (2009) find boards identified as ineffective in the media increase the number of outside directors and discontinue the use of staggered boards.

${ }^{18}$ We use CEO compensation for the first full fiscal year after the annual meeting, as opposed to compensation in the year of the annual meeting, because the compensation in the year of the meeting is likely to have been established before the meeting date. That is, the annual meeting date for fiscal period $t$ is in fiscal period $t+1$. Given that the meeting is generally several months into period $t+1$, the compensation contract for period $t+1$ is most likely established by the meeting date. Therefore, the board will react to a vote related to period $t$ by adjusting the compensation contract in the next available period, which is period $t+2$. 


$$
\begin{aligned}
\log \left(\text { Comp }_{i, t}\right)= & \beta_{0}+\beta_{1} * \log (\text { tenure })_{i, t}+\beta_{2} * \log \left(\text { sales }_{i, t-1}+\beta_{3} * \text { BTM }_{i, t-1}+\beta_{4} * \text { Return }_{i, t}+\beta_{5} * \text { Return }_{i, t-1}\right. \\
& +\beta_{6} * \text { ReturnOnAssets }_{i, t}+\beta_{7} * \text { ReturnOnAssets }_{i, t-1}+\varepsilon_{i, t}
\end{aligned}
$$

where $\log \left(\mathrm{Comp}_{t}\right)$ is defined as the logarithm of total compensation (calculated as the sum of salary, bonus, long-term incentive plan payouts, the value of restricted stock grants, the value of options granted during the year, and any other annual pay for the CEO in year $t)$. $\log (\text { tenure })_{t}$ is the logarithm of the CEO's tenure in years at the end of year t. $\log (\text { sales })_{t-1}$ is the logarithm of firm sales for year $t-1 . B T M_{t-1}$ is the book value of assets / (book value of liabilities + market value of equity) at the end of year $t-1$. Return $n_{t}$ is the firm's return for year $t$. Return $n_{t-1}$ is the firm's return for year $t-1$. ReturnOnAsset $s_{\mathrm{t}}$ is income before extraordinary items divided by average total assets for year $t$. ReturnOnAssets $\mathrm{s}_{\mathrm{t}-1}$ is income before extraordinary items divided by average total assets for year $t$ - 1 . Equation (6) is estimated using OLS, where fixed effects for industry (2digit SIC) and year are included. We calculate expected compensation by exponentiating the expected value from equation (6). We then obtain our proxy for excess compensation for each observation by subtracting expected compensation from total compensation; that is, Total Compensation minus Expected Compensation equals Excess Compensation.

To capture the association between approval and subsequent excess compensation, we estimate the following model using OLS:

$$
\begin{aligned}
\text { ExcessComp }_{i, t+2}= & \beta_{0}+\beta_{1} * \operatorname{APPR}_{i, t}+\beta_{2} * \operatorname{CONTRACT}_{i, t} \\
& +\beta_{3} * \text { CONTRACT } T_{i, t} * \operatorname{APPR}_{i, t}+\text { CONTROLS }_{i}+\varepsilon_{i, t},
\end{aligned}
$$

where ExcessComp Ex+2 $_{t+2}$ is excess CEO compensation for the first full fiscal year after the annual meeting, $A P P R$ is the relevant measure of approval, CONTRACT is a dummy variable, which is 1 if the CEO has a written employment agreement in place, and CONTROLS are other measures of performance as previously discussed. The inclusion of the CONTRACT variable is based on recent research by Gillan, Hartzell, and Parrino (2009) demonstrating that CEOs at nearly 50\% of S\&P 500 firms have written (explicit) employment agreements that stipulate compensation over a period of time and thus limit the sensitivity of compensation to perceptions of performance. Thus, we predict that the interactive term will have a coefficient with a sign 
opposite to the sign of the $A P P R$ coefficient. We obtain the contract data from Gillan et al. (2009) who classify the existence of CEO contracts as of January 1, 2000. Finally, we delete observations with CEO turnovers in the following two fiscal years after the annual meeting date in order to ensure the same CEO is employed both at the annual meeting date for fiscal period $t$ through fiscal year $t+2$.

The results of the excess compensation analysis are reported in Table 7. The relations between the approval metrics and subsequent excess compensation are in the predicted directions for all approval variables and are statistically significant for all approval variables except BRD_APPR. Overall, these findings are consistent with approval having a positive association with future compensation. In addition, there is some, albeit quite weak, evidence of explicit employment contracts mitigating this association. More specifically, all CEO approval interaction coefficient estimates are in the predicted direction, but only the CEO_APPR interaction loads significantly (at the $10 \%$ level).

\subsection{Acquisitions}

We hypothesize that poorly perceived boards are associated with better-received acquisitions and fewer acquisitions in the future. There are two potential reasons, which are not mutually exclusive. First, external financiers and/or board members are likely to be less willing to accept, and more diligent in their scrutiny of, proposed acquisitions when the board is perceived to be managing poorly, limiting cash flow available for proposed acquisitions and/or improving acquisition decisions. External financiers are more likely to exhibit such behavior because they are not confident in management's ability to identify and negotiate a sound acquisition. Some board members, particularly external board members, are likely to exhibit such behavior because they are less trusting of the judgment and capabilities of the CEO's management team, they are distancing themselves from a poorly perceived management team, and/or they are acting to enhance or revive their own reputation by helping the firm make better decisions. Second, firms with poorly perceived board performance are likely to have poorer cash positions, thereby reducing the cash available for investment decisions. 
To test whether low approval is associated with better-received future acquisitions and fewer future acquisitions, we collect a list of mergers and acquisitions for foreign and domestic targets from SDC's U.S. Mergers and Acquisitions Database. We follow prior literature (e.g., Fuller, Netter, and Stegemoller, 2002) and eliminate acquisitions where the dollar value of the target firm is not disclosed, the deal value is less than one million dollars, or the bidder is acquiring less than $50 \%$ of the target firm. We also eliminate joint ventures and mergers announced by the same firm within a five-day trading window.

We calculate the market response to the acquisition announcement, $A C Q_{-} C A R$, as the average five-day market model cumulative abnormal return estimated using CRSP-population data from a 255 -day estimation period ending 46 days before the acquisition announcement. $A C Q \_C A R$ is determined for all acquisition announcement dates taking place in the 12 months subsequent to the annual meeting. Columns 1-3 of Table 8 report the regression results for the following model:

$$
A C Q \_C A R_{i, t+1}=\beta_{0}+\beta_{1} * A P P R_{i, t}+C O N T R O L S_{i}+\varepsilon_{i, t},
$$

Consistent with our hypothesis, there is a negative relationship between board approval and the average subsequent acquisition announcement market return. QUINT_BRD_APPR, $B R D \_A P P R$, and $B Q 1$ have the predicted signs and are statistically significant at the $1 \%, 5 \%$, and $10 \%$ levels, respectively.

To assess whether subsequent acquisition frequency decreases for firms with low votes, we define $A C Q \_F E Q$ as the number of acquisitions that take place in the 12 months subsequent to the annual meeting. Columns 4-6 of Table 8 report the ordered logistic regression results for the following model.

$$
A C Q_{-} F R E Q_{i, t+1}=\beta_{0}+\beta_{1} * A P P R_{i, t}+C_{\text {CONTROLS }}+\varepsilon_{i, t},
$$

Consistent with our hypothesis, we find a positive (negative) coefficient on QUINT_BRD_APPR (BQ1), significant at the $5 \%$ level. The coefficient on BRD_APPR is positive as predicted, but insignificant at conventional levels. Overall, these combined results indicate an inverse relationship between performance and subsequent acquisition activity. 


\subsection{Divestitures}

When management is performing poorly, a firm's assets are likely to be underperforming to a greater extent so the returns on divestitures of assets should be higher. In addition, when management is performing poorly, there should be more divestitures because there are more valuable divesture opportunities, as well as a greater demand for divestiture cash flows to counter poor operating cash flows. As a consequence, we hypothesize that low approval, which reflects perceptions of poor management, will be associated with better-received divestitures and more divestiture activity.

To test these hypotheses, we collect a list of U.S. divestitures from Securities Data Corporation (SDC). We eliminate divestitures where the dollar value of the divested firm is not disclosed, the deal value is less than one million dollars, or divestitures for the same firm are announced within a five-day trading window. To examine the market response to the divestiture activity following the vote, we calculate $D I V \_C A R$ as the average five-day market model cumulative abnormal return estimated using CRSP-population data from a 255-day estimation period ending 46 days before the divestiture announcement for all divestiture announcement dates that took place in the 12 months subsequent to the annual meeting.

Columns 1-3 of Table 9 report the OLS regression results for the following model:

$$
\text { DIV_CAR }{ }_{i, t+1}=\beta_{0}+\beta_{1} * A P P R_{i, t}+\text { CONTROLS } S_{i,}+\varepsilon_{i, t} .
$$

Consistent with our expectations, there is a negative relationship between board approval and the average subsequent divestiture market return. $Q U I N T \_B R D \_A P P R, B R D \_A P P R$, and $B Q 1$ all have the predicted signs and are statistically significant at the $1 \%$ level.

To test whether subsequent divestiture activity increases for firms with low votes, we define DIV_FREQ as the number of divestitures taking place in the 12 months subsequent to the annual meeting and run the following ordered logistic regression model:

$$
D I V_{-} F R E Q_{i, t+1}=\beta_{0}+\beta_{1} * A P P R_{i, t}+C_{\text {ONTROLS }}+\varepsilon_{i, t} .
$$

The results obtained from the regression model are reported in Columns 4-6 of Table 9, and are consistent with our prediction. Specifically, the coefficients on $Q U I N T \_B R D \_A P P R$ and $B Q 1$ 
are statistically significant at the $5 \%$ level in the predicted directions. The coefficient on $B R D \_A P P R$ has the predicted sign, although it is only significant at the $10 \%$ level. Overall, the combined results in Table 9 suggest that lower approval is associated with better-received subsequent divestitures as well as an increase in the number of subsequent divestitures.

\section{Supplementary analysis}

\subsection{Change in voting behavior}

This paper examines whether measures of investor perceptions of boards are associated with retention and investment decisions. A natural follow-up analysis ascertains whether subsequent changes in perceptions are associated with these decisions. Hence, we estimate the change in perceptions as a function of the average five-day CAR around the events:

$$
C H G_{-} B R D \_A P P R_{i, t}=\beta_{0}+\beta_{1} * E V E N T \_C A R_{i, t}+\varepsilon_{i, t},
$$

where EVENT_CAR represents CARs surrounding the event announcement: CEO turnovers $\left(C E O \_C A R\right)$, acquisitions $\left(A C Q \_C A R\right)$, or divestitures $\left(D I V \_C A R\right)$. A positive coefficient on EVENT_CAR indicates that an event viewed favorably (poorly) by the market is associated with a positive (negative) change in board approval. In untabulated results, we find that only $C E O \_C A R$ is significantly positive $(p$-value $=0.034)$, indicating that adjustments in acquisition and divestiture activity for the year do not have a significant effect on perceptions. One potential reason for this result is that perceptions are difficult to change with investment decisions and can only be altered by an action as drastic as replacing the leader of the current management team.

\subsection{Decomposing the approval measures}

The approval measure used in our primary analyses is a function of how shareholders choose to exercise their voting rights. It is not immediately clear, however, which voting choice drives the information content of the approval measure. In particular, a shareholder faces three alternatives related to voting proxies in director elections: vote for the board member (affirmation), withhold vote for the board member (rejection), or not vote at all (apathy). The numerator of our summary approval measure (votes for) reflects the number of shareholders who chose to affirm a director, or who are apathetic but whose broker votes their street share to affirm 
a director. The denominator (votes cast) reflects the number of shareholders who choose not to be apathetic, or whose broker votes their street share in the event they are apathetic. Hence, the approval measures are a function of both voter turnout and how the votes are cast.

To better understand the information content of each component, we decompose each approval measure into two statistics, affirmation and apathy, where affirmation is defined as: votes for / votes outstanding and apathy is defined as: votes outstanding / (votes for + votes withheld). We obtain the number of votes outstanding from proxy filings made prior to the annual meeting. We then revisit the turnover announcement tests and run the following regression:

$$
C E O \_C A R_{i, t+1}=\beta_{0}+\beta_{1} * A F F I R M_{i, t}+\beta_{2} * A P A T H Y_{i, t}+\text { CONTROLS }_{i}+\varepsilon_{i, t} .
$$

Consistent with the results in Table 4, we expect the AFFIRM measures to be negatively related to the announcement period returns (i.e., $\beta_{1}<0$ ). However, we offer no explicit prediction for the controlled relationship between $A P A T H Y$ and announcement period returns. In untabulated results, we find that both the quintiled and continuous measures of board affirmation are negative and significant at the 5\% level. In contrast, the corresponding apathy measures are insignificant at conventional levels. The results using decomposed CEO approval measures are qualitatively similar, though less significant.

We also revisit the forced CEO turnover prediction models by running logit regressions of the following form:

$$
C E O \_T U R N_{i, t+1}=\beta_{0}+\beta_{1} * A F F I R M_{i, t}+\beta_{2} * A P A T H Y_{i, t}+\beta_{3} * A G E_{i, t}+\text { CONTROLS }_{i,}+\varepsilon_{i, t} .
$$

Consistent with the results in Table 5, we expect the AFFIRM measures to be negatively related to forced CEO turnover (i.e., $\beta_{1}<0$ ). Again, we have no explicit prediction on how APATHY should be related to forced CEO turnover. In untabulated results, the board and CEO affirmation measures have the expected negative association with forced CEO turnovers. However, in contrast to results from equation 12 , the coefficients on the continuous measure of board apathy and both the quintiled and continuous measures of CEO apathy are negative and statistically significant. 
Overall, this evidence suggests that the information content of the board and CEO approval measures is driven primarily by the decisions of voting shareholders - to affirm or withhold. Shareholder apathy, or equivalently turnout, fails to add substantially to the affirmation statistic in terms of shareholder perceptions. Shareholder apathy, however, appears to play a role in predicting turnover, consistent with apathy reflecting shareholder 'voting' activism.

\subsection{Approval as a proxy for governance}

Although we view the vote tallies as a measure of board performance, an alternative view is that vote tallies simply reflect governance attributes rather than how well the board is performing given those attributes. ${ }^{19}$ In order to provide some evidence as to whether the vote tallies reflect governance attributes, we rerun our analyses summarized in Tables 4 through 9 incorporating a number of governance variables in addition to the performance measures $\left(R E T_{t}, R E T_{t-1}, R E T_{t-2}\right.$, $R O A_{t}, R O A_{t-1}, R O A_{t-2}$, and $\left.C H G_{-} I N S T_{-} O W N\right)$ : percentage of institutional ownership, number of blockholders, percentage of blockholders, G-score, board size, and percentage of board insiders. $^{20}$

To ascertain whether the information content of the approval measures is captured by the combined performance and governance statistics, we re-run the analyses using the observations where data is available for all 13 performance and governance measures. Untabulated results indicate that despite the significant number of competing controls and limited sample sizes in several of our tests, the approval measures generally load in the predicted directions and retain their statistical significance. ${ }^{21}$ In fact, in a few cases, the results become even stronger. The few cases where the results are somewhat weaker are likely due to the combined effects of increasing

\footnotetext{
${ }^{19}$ For example, shareholders might withhold votes from the board when the institutions of governance are deemed weak (e.g., too many inside directors) as opposed to when the board members are actually making poor decisions. Further, the extent of institutional holdings or number of blockholders, which are often viewed as governance attributes, could be an important driver of voting outcomes because these large shareholders are more likely to vote more diligently.

${ }^{20}$ We obtain the percentage of institutional ownership from Thompson Financial 13(f) institutional shareholder data. The number and percentage of blockholders are obtained from the Blockholders dataset on WRDS. The G-Score and percentage of board insider measures are obtained from Risk Metrics (IRRC) database. Board size is obtained from data provided by The Corporate Library.

${ }^{21}$ The results from this analysis are available upon request.
} 
the number of dependent variables and significantly reducing already small sample sizes. Hence, the information content of the approval measures appears to be robust to a number of performance and governance variables, suggesting that the voting poll is not only a useful summary statistic, but also appears to reflect information not captured by a variety of performance and governance variables.

\section{Concluding comments}

Many argue that uncontested director elections are meaningless because directors up for election almost surely prevail. We provide evidence, however, that vote tallies still play a meaningful role by reflecting investor perceptions of board performance. First, vote approval measures are related to other factors expected to reflect or influence investor perceptions of board performance. Second, the approval measures are associated with stock price behavior surrounding CEO turnover announcements in a manner consistent with those measures reflecting investor perceptions, even after controlling for other contemporaneously available performance and governance metrics. Finally, we provide evidence that vote tallies are associated with several

future significant corporate events in a manner consistent with the vote outcomes reflecting board performance (i.e., CEO and board member retention, CEO compensation, divestitures, and acquisitions).

The results of our study suggest that uncontested director election outcomes can serve as a useful measure of board performance. At a minimum, board approval complements other standard performance measures. Our results also suggest that board approval measures can enrich governance studies by directly evaluating management, as opposed to examining the governance structures in place within the firm (e.g., board size or board independence).

Our findings are also applicable to recent proposals calling for majority voting in director elections. Our evidence suggests that while uncontested votes reflect investor perceptions of board performance, such proposals will have little effect unless they significantly alter voting behavior. An approval measure of $80 \%$ falls into the lowest quintile of our approval measures, indicating low relative approval, but the tally still far exceeds the $50 \%+$ majority hurdle. 


\section{References}

Andersen, R., Mansi, S., Reeb, D., 2004. Board characteristics, accounting reporting integrity, and the cost of debt. Journal of Accounting and Economics 37, 315-342.

Ashbaugh-Skaife, H., Collins, D., LaFond, R., 2006. The effects of corporate governance on firms' credit ratings. Journal of Accounting and Economics 42, 203-243.

Balsam, S., Miharjo, S., 2007. The effect of equity compensation on voluntary executive turnover. Journal of Accounting and Economics 43, 95-119.

Bebchuk, L.A., 2007. The myth of the shareholder franchise. Virginia Law Review. 93 (3), 675.

Bethel, B.E., Gillan, S.L., 2002. The impact of the institutional and regulatory environment on shareholder voting. Financial Management Journal 31, 29-54.

Borokhovich, K.A., Parrino, R., Trapani, T., 1996. Outside directors and CEO selection. The Journal of Financial and Quantitative Analysis 31, 337-355

Cai, J., Garner, J.L., Walkling, R.A., 2009. Electing directors. Journal of Finance, forthcoming.

CalSTRS, 2003. Financial Responsibility Criteria as of July 2003. [Electronic version].

Retrieved on September 17, 2006, from

http://www.calstrs.com/Investments/finRespCriteria.aspx.

Carleton, W.T., Nelson, J.M., Weisbach, M.S., 1998. The influence of institutions on corporate governance through private negotiations: evidence from TIAA-CREF. The Journal of Finance 53, 1335-1362.

Collins, D., DeAngelo, L., 1990. Accounting information and corporate governance: market and analyst reactions to earnings of firms engaged in proxy contests. Journal of Accounting and Economics 13, 213-247.

Core, J., Holthausen, R. Larcker, D., 1999. Corporate governance, chief executive officer compensation, and firm performance. Journal of Financial Economics 51, 371-406.

Core, J., Guay, W., Larcker, D., 2008. The power of the pen. Journal of Financial Economics 88, $1-25$.

DeAngelo L., 1988. Managerial competition, information costs, and corporate governance: the use of accounting performance measures in proxy contests. Journal of Accounting and Economics 10, 3-36.

DeFond, M., Park, C., 1999. The effect of competition on CEO turnover. Journal of Accounting and Economics 27, 35-56. 
Del Guercio, D., Wallis, L., Woidtke, T., 2008. Do board members pay attention when institutional investors 'Just Vote No'?: CEO and director turnover associated with shareholder activism. Journal of Financial Economics 90, 84-103.

Denis, D., Denis, D., 1995. Performance changes following top management dismissals. Journal of Finance 50, 1029-1057.

Dodd, P., Warner, J.B., 1983. On corporate governance: a study of proxy contests. Journal of Financial Economics 11, 401-438.

Downs, A., 1957. An Economic Theory of Democracy. Harper \& Row, New York.

Engel, E., Hayes, R.M., Wang, X., 2003. CEO turnover and properties of accounting information. Journal of Accounting and Economics 36, 197-226.

Fama, E.F., Jensen, M.C., 1983. Separation of ownership and control. Journal of Law and Economics, XXVI.

Fama, E.F., French, K.R. 1997. Industry costs of equity. Journal of Financial Economics 43, 153193.

Farrell, K., Whidbee, D., 2003. Impact of firm performance expectations on CEO turnover and replacement decisions. Journal of Accounting and Economics 36, 165-196.

Ferri, F., Markarian, G., Sandino, T., 2004. Stock option expensing: evidence from shareholders' votes. Unpublished working paper. Harvard Business School.

Ferri, F., Ertimur, Y., Stubben, S., 2008. Board of directors' responsiveness to shareholders: evidence from majority-approved shareholder proposals. Unpublished working paper. Harvard Business School.

Fischer. P. E., 2007. Shareholder voting, share prices, and investor disagreement. Unpublished working paper. Penn State University.

Froot, K.A., 1989. Consistent covariance matrix estimation with cross-sectional dependence and heteroskedasticity. Journal of Financial and Quantitative Analysis 24, 333-355.

Fuller, K., Netter, J., Stegemoller, M., 2002. What do returns to acquiring firms tell us? Evidence from firms that make many acquisitions. The Journal of Finance, 57, 1763-1793.

Gillan, S.L., Hartzell, J.C., Parrino, R., 2009. Explicit vs. implicit contracts: evidence from CEO employment agreements. Journal of Finance, forthcoming.

Gillan, S.L., Starks, L.T., 2000. Corporate governance proposals and shareholder activism: the role of institutional investors, Journal of Financial Economics 57, 275-305.

Gompers, P.A., Ishii, J.L., Metrick, A. 2003. Corporate governance and equity prices. Quarterly Journal of Economics, 118, 107-155. 
Goyal, V.K., Park, C.W., 2002. Board leadership structure and CEO turnover. Journal of Corporate Finance 8, 49-66.

Hermalin, B.E., Weisbach, M., 1988. The determinants of board composition. Rand Journal of Economics 19, 589-606.

Huber P.J., 1967. The behavior of maximum likelihood estimates under nonstandard conditions. Proceedings of the Fifth Berkeley Symposium on Mathematical Statistics and Probability. University of California Press, Berkeley, CA.

Huson, M.A., Parrino, R., Starks, R.T., 2001. Internal monitoring mechanism and CEO turnover: a long-term perspective. The Journal of Finance 56, 2265-2297.

Klein, A., 2002. Audit committee, board of director characteristics, and earnings management. Journal of Accounting and Economics 3, 375-400.

Ittner, L, Larcker, D., 2001. Assessing empirical research in managerial accounting: a valuebased management perspective. Journal of Accounting and Economics 32, 349-410.

Iwata, E., 2004. Businesses say corporate governance can go too far. USA Today, Money Section: 1B.

Lambert, R.A., Larcker, D.F., 1987. An analysis of the use of accounting and market measures of performance in executive compensation contracts. Journal of Accounting Research 25, 85-125.

Larcker, D., Richardson, S., Tuna, I., 2007. Corporate governance, accounting outcomes, and organizational performance. The Accounting Review 82, 963-1008.

Louis, H., Joe, J.R., Robinson, D., 2009. Managers' and investors' responses to media exposure of board ineffectiveness. The Journal of Financial and Quantitative Analysis, forthcoming.

Lowenstein, L., 1988. What's Wrong with Wall Street? Addison-Wesley, Reading, MA.

Monks, R.A.G., Minow, N. 2004. Corporate Governance, 3rd ed. Blackwell, Oxford.

Morgenson, G., 2006. Soviet-style proxies, made in the USA. The New York Times, June 25, 2006 online edition.

Morck, R., Schleifer, A., Vishny, A.R., 1989. Alternative mechanisms for corporate control. The American Economic Review 79, 842-852.

Mulherin, J.H., Poulsen, A.B. 1998. Proxy contests and corporate change: implications for shareholder wealth. Journal of Financial Economics 47, 279-313.

Murphy, K. 1985. Corporate performance and managerial remuneration: An empirical analysis. Journal of Accounting and Economics 7, 11-42.

Parrino, R., 1997. CEO turnover and outside succession: a cross-sectional analysis. Journal of Financial Economics 46, 165-197. 
Parrino, R., Sias, R., Starks, L., 2002. Voting with their feet: institutional changes around forced CEO turnover. Journal of Financial Economics 68, 3-46.

Pound, J., 1988. Proxy contests and the efficiency of shareholder oversight. Journal of Financial Economics 20, 237-265.

Shivdasani, A., 1993. Board composition, ownership structure, and hostile takeovers. Journal of Accounting and Economics 16, 167-199.

Smith, M.P., 1996. Shareholder activism by institutional investors: evidence from CalPERS. The Journal of Finance 51, 227-252.

Warner, J.B., Watts, R.L., Wruck, K.H., 1988, Stock prices and top management changes. Journal of Financial Economics 20, 432-460.

Weisbach, M., 1988. Outside directors and CEO turnover. Journal of Financial Economics 20, 159-188.

White, H., 1980. A heteroskedasticity-consistent covariance matrix estimator and a direct test for heteroskedasticity. Econometrica 48, 817-830. 
Table 1

\section{Sample Construction}

The initial sample consists of the Standard \& Poor's 500 list as of January 1, 2000, representing 2,500 firm-year observations across the five years ended December 31, 2004. As described below, 1,003 observations are deleted to focus the sample on non-utility firms, to obtain complete data, to avoid observations with dual CEOs, to avoid observations subject to vote no campaigns or proxy fights, and to avoid observations with dual class shares related to family owned shares. To enable analyses of CEO approval, an additional 670 observations are eliminated by restricting the sample to those firms that have a CEO standing for election in the current year.

No. firm/year

observations

\section{Board Analysis}

Standard \& Poor's 500 as of January 1, 2000

2,500

that are not utilities within SIC 4900-4999

2,290

and that are not missing board approval data

1,795

and that are not missing prior-year Compustat or CRSP data

1,660

and that are not missing institutional holding-change data from Thomson Financial

1,564

and that do not report dual CEOs

1,552

and that are not subjects of vote no campaigns or proxy fights

1,512

and that do not have dual class shares related to family owned shares

CEO Analysis

and that have a CEO standing for election in the current year 
Table 2

\section{Distributional Statistics for Annual Board and CEO Approval}

BRD_APPR is the median ratio of "for" votes to total votes cast across board members standing for election within a firm-year. CEO_APPR is the ratio of "for" votes to total votes cast for the CEO standing for election within a firm-year. Panel A (Panel B) provides annual mean and median BRD_APPR (CEO_APPR) statistics. Means and medians for years 2001 through 2004 are compared with their respective prior year means and medians using two-tail T and Wilcoxon tests, respectively. For the years 2001 to 2004 , the means of each quintile are compared with the respective prior year means using the two-tail T test. Means of the first and fifth quintiles are compared using the two-tail T test. ${ }^{* *},{ }^{* *}$, and * indicate significant differences at the $1 \%, 5 \%$, and $10 \%$ levels, respectively.

PANEL A - Board Approval

\begin{tabular}{|c|c|c|c|c|c|c|c|c|c|c|c|}
\hline Variable & Obs & Mean & Median & \multicolumn{7}{|c|}{ Means } & $\begin{array}{c}\text { Difference } \\
\text { Q5 minus Q1 }\end{array}$ \\
\hline 2000 & 284 & 0.980 & 0.987 & 0.861 & 0.945 & 0.980 & 0.988 & 0.991 & 0.995 & 0.999 & $0.050 * \star \star$ \\
\hline 2001 & 307 & 0.974 ** & 0.986 * & 0.827 & 0.924 ** & $0.976 * * *$ & * $\quad 0.986$ *** & * $0.990 * * *$ & * 0.994 & 0.997 & $0.070 * * *$ \\
\hline 2002 & 318 & 0.970 & 0.983 *** & 0.766 & 0.912 & $0.974^{* \star *}$ & * $\quad 0.982$ *** & * $\quad 0.987$ *** & * $\quad 0.992$ *** & 0.996 & 0.080 *** \\
\hline 2000-2004 combined & 1497 & 0.964 & 0.980 & 0.720 & 0.898 & 0.966 & 0.978 & 0.986 & 0.990 & 0.998 & $0.092 * \star \star *$ \\
\hline
\end{tabular}

PANEL B - CEO Approval

\begin{tabular}{|c|c|c|c|c|c|c|c|c|c|c|c|}
\hline Variable & Obs & Mean & Median & \multicolumn{7}{|c|}{ Means } & $\begin{array}{c}\text { Difference } \\
\text { Q5 minus Q1 }\end{array}$ \\
\hline \multicolumn{12}{|l|}{ CEO_APPR } \\
\hline 2000 & 162 & 0.969 & 0.986 & 0.823 & 0.900 & 0.973 & 0.986 & 0.992 & 0.995 & 1.000 & $0.095 * * *$ \\
\hline 2001 & 176 & 0.968 & 0.986 & 0.803 & 0.897 & 0.971 & 0.986 & $0.990 * * *$ & * 0.995 & 0.999 & $0.098 * * *$ \\
\hline 2002 & 174 & 0.962 & 0.984 * & 0.757 & 0.873 * & 0.971 & $0.983 * * *$ & * $0.988 * \star \star$ & * 0.993 *** & 0.999 & $0.120 * \star \star$ \\
\hline 2000-2004 combined & 827 & 0.962 & 0.980 & 0.743 & 0.885 & 0.968 & 0.979 & 0.986 & 0.993 & 0.999 & $0.108 * * *$ \\
\hline
\end{tabular}


Table 3

\section{Pearson and Spearman Correlations Among Key Regression Variables}

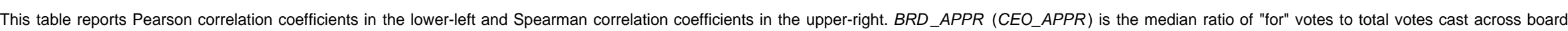

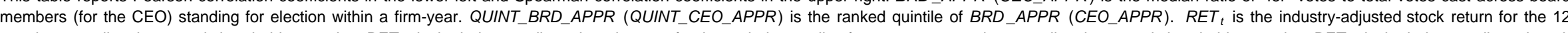

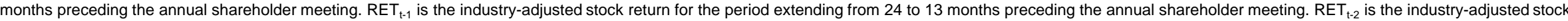

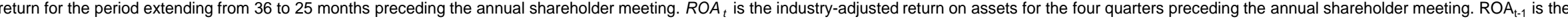

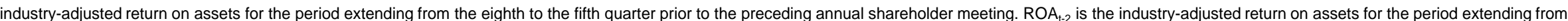

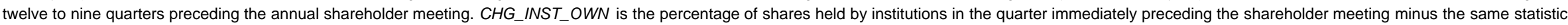
one year earlier. ${ }^{* \star *},{ }^{* *}$, and ${ }^{*}$ indicate two-tail statistical significance at the $1 \%, 5 \%$, and $10 \%$ levels, respectively.

\begin{tabular}{|c|c|c|c|c|c|c|c|c|c|c|c|}
\hline & CEO_APPR & $\begin{array}{c}\text { QUINT } \\
\text { CEO_APPR }\end{array}$ & $B R D \_A P P R$ & $\begin{array}{c}\text { QUINT } \\
\text { BRD_APPR }\end{array}$ & $R E T_{t}$ & $R E T_{t-1}$ & $R E T_{t-2}$ & $R O A_{t}$ & $R O A_{t-1}$ & $R O A_{t-2}$ & $\begin{array}{c}\text { CHG_INST } \\
\text { OWN }\end{array}$ \\
\hline CEO_APPR & & $0.906 * \star *$ & 0.824 *** & 0.720 *** & $0.161 * \star \star$ & $0.115 * \star \star$ & 0.176 *** & $0.139 * \star \star$ & 0.082 * & 0.058 * & -0.011 \\
\hline QUINT_CEO_APPR & $0.654 * \star \star$ & & $0.707^{\star \star \star}$ & 0.786 *** & $0.119 * \star \star$ & 0.082 ** & $0.123 * \star *$ & $0.140 * \star \star$ & $0.092^{* \star \star}$ & $0.088^{* *}$ & 0.011 \\
\hline$B R D \_A P P R$ & $0.797 * \star *$ & $0.516 * * \star$ & & $0.841 * * *$ & $0.158 * * *$ & $0.197 * \star \star$ & $0.198 * \star \star$ & 0.176 *** & $0.121 * \star \star$ & $0.083 * \star \star$ & -0.028 \\
\hline QUINT_BRD_APPR & $0.524 * \star \star$ & $0.784^{\star * *}$ & $0.590 * * *$ & & $0.100 * * *$ & $0.125^{\star * \star}$ & $0.115 * * *$ & $0.160 * \star \star$ & $0.119 * * \star$ & $0.098^{\star * \star}$ & 0.006 \\
\hline$R E T_{t}$ & 0.050 & $0.085 * \star \star$ & 0.035 & 0.078 *** & & $-0.101 * \star \star$ & 0.026 & $0.167^{* * \star}$ & 0.042 & 0.008 & $0.207^{* \star \star}$ \\
\hline$R E T_{t-1}$ & 0.002 & 0.054 & $0.055 * *$ & $0.084 * * *$ & -0.034 & & -0.025 & $0.268^{* * \star}$ & $0.234^{* \star *}$ & $0.104^{* \star *}$ & -0.166 *** \\
\hline$R E T_{t-2}$ & 0.065 * & $0.081 * *$ & $0.080 * * *$ & $0.096 * * *$ & -0.008 & 0.043 * & & $0.228^{\star * \star}$ & $0.237^{\star \star \star}$ & $0.184^{\star \star \star}$ & -0.055 ** \\
\hline$R O A_{t}$ & 0.021 & $0.113 * \star *$ & 0.084 *** & 0.131 *** & $0.088 * * *$ & 0.164 *** & 0.129 *** & & 0.801 *** & $0.687^{* \star *}$ & -0.040 \\
\hline$R O A_{t-1}$ & -0.025 & $0.070 * *$ & 0.053 ** & $0.099 * * *$ & -0.034 & $0.129 * \star *$ & $0.150^{* * *}$ & 0.784 *** & & $0.768^{\star \star \star}$ & $-0.070^{* * *}$ \\
\hline$R O A_{t-2}$ & -0.003 & $0.100 * \star \star$ & 0.044 * & $0.082 * \star \star$ & -0.044 * & 0.011 & $0.093 * \star \star$ & 0.678 *** & $0.785 * \star \star$ & & -0.026 \\
\hline CHG_INST_OWN & -0.028 & -0.019 & -0.038 & -0.003 & $0.171 * * *$ & 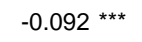 & -0.009 & -0.012 & -0.058 ** & -0.020 & \\
\hline
\end{tabular}


Table 4

Approval and Abnormal Returns Surrounding CEO Turnover Announcements

This table reports coefficients and, in parentheses, t-statistics for OLS regression models that explain 5-day cumulative abnormal returns surrounding CEO turnovers, both without control variables (i.e., Short Model) and with control variables (i.e., Long Model). Panel A shows the results where the approval measure (APPR) is QUINT_BRD_APPR BRD_APPR, QUINT_CEO_APPR, or CEO_APPR. Panel B incorporates the effect of the replacement CEO type (i.e., insider or outsider). The CEO turnover announcement return, CEO CAR ${ }_{\mathrm{t}+1}$, is the 5-day market model cumulative abnormal return estimated using CRSP-population data from a 255-day estimation period ending 46 days before the announcement date. QUINT_BRD_APPR (QUINT_CEO_APPR) is the quintile rank of BRD_APPR (CEO_APPR) within each of the five years of the sample period. CONTROLS are performance measures (i.e., $R E T_{\mathrm{t}}, R E T_{\mathrm{t}-1}, R E T_{\mathrm{t}-2}, R O A_{\mathrm{t}}, R O A_{\mathrm{t}-1}, R O A_{\mathrm{t}-2}, C H G_{-} I N S T_{-} O W N$ as previously defined in Table 3). INSIDER is one when the replacement CEO is an insider and zero otherwise. We cluster by firm for all regressions and year fixed effects are included in theBRD_APPR and CEO_APPR regressions.

There are 167 turnovers examined in the board turnover analyses and only 82 in the CEO analyses, since not all of the 167 CEOs stood for election in the year before the turnover. CEO turnovers are included if a CEO departure announcement occurs during the period beginning the day after the shareholder meeting and ending the day of the subsequent shareholder meeting. 18 CEO turnovers were excluded from this analysis due to incomplete return data or because they were announced simultaneously with merger/acquisition announcements. ${ }^{\star *},{ }^{* \star}$ and $*$ indicate statistical significance at the $1 \%, 5 \%$, and $10 \%$ levels, respectively, in one-tail tests where the sign is predicted and in two-tail tests where the sign is not predicted.

PANEL A - 5-day abnormal returns $(-3,+1)$ on approval measures

\begin{tabular}{|c|c|c|c|c|c|c|c|c|c|}
\hline & Hyp. sign & Short model & Long model & Short model & Long model & Short model & Long model & Short model & Long model \\
\hline Intercept & & $\begin{array}{l}0.033 \text { ** } \\
(2.25)\end{array}$ & $\begin{array}{l}0.031 \text { ** } \\
(2.23)\end{array}$ & $\begin{array}{l}0.240 \text { *** } \\
(2.77)\end{array}$ & $\begin{array}{l}0.240 \text { ** } \\
(2.60)\end{array}$ & $\begin{array}{l}0.050 \text { *** } \\
(2.79)\end{array}$ & $\begin{array}{l}0.044^{\star \star} \\
(2.54)\end{array}$ & $\begin{array}{c}0.168 \\
(1.60)\end{array}$ & $\begin{array}{l}0.226 \text { * } \\
(1.91)\end{array}$ \\
\hline QUINT_BRD_APPR & - & $\begin{array}{l}-0.008 \text { ** } \\
(-1.67)\end{array}$ & $\begin{array}{l}-0.006 \text { * } \\
(-1.51)\end{array}$ & & & & & & \\
\hline BRD_APPR & - & & & $\begin{array}{l}-0.216 \text { *** } \\
(-2.47)\end{array}$ & $\begin{array}{l}-0.204 \text { ** } \\
(-2.21)\end{array}$ & & & & \\
\hline QUINT_CEO_APPR & - & & & & & $\begin{array}{l}-0.014 \text { ** } \\
(-2.18)\end{array}$ & $\begin{array}{l}-0.015^{* \star *} \\
(-2.57)\end{array}$ & & \\
\hline CEO_APPR & - & & & & & & & $\begin{array}{l}-0.150 \text { * } \\
(-1.29)\end{array}$ & $\begin{array}{l}-0.210 \text { ** } \\
(-1.74)\end{array}$ \\
\hline CONTROLS & & NO & YES & NO & YES & NO & YES & NO & YES \\
\hline $\mathrm{R}^{2}$ & & 0.018 & 0.096 & 0.044 & 0.144 & 0.042 & 0.257 & 0.046 & 0.311 \\
\hline \# of obs & & 167 & 167 & 167 & 167 & 82 & 82 & 82 & 82 \\
\hline & Hyp. Sign & Short Model & Long Model & Short Model & Long Model & Short Model & Long Model & Short Model & Long Model \\
\hline Intercept & & $\begin{array}{c}0.038 \\
(1.38)\end{array}$ & $\begin{array}{c}0.031 \\
(1.15)\end{array}$ & $\begin{array}{l}0.354 \text { *** } \\
(2.90)\end{array}$ & $\begin{array}{l}0.326 \text { *** } \\
(2.77)\end{array}$ & $\begin{array}{l}0.092 \text { ** } \\
(2.32)\end{array}$ & $\begin{array}{l}0.089 \text { ** } \\
(2.77)\end{array}$ & $\begin{array}{l}0.339 \text { ** } \\
(2.21)\end{array}$ & $\begin{array}{c}0.289 \\
(1.83)\end{array}$ \\
\hline QUINT_BRD_APPR & - & $\begin{array}{l}-0.013 \\
(-1.20)\end{array}$ & $\begin{array}{l}-0.005 \\
(-0.69)\end{array}$ & & & & & & \\
\hline BRD_APPR & - & & & $\begin{array}{l}-0.344 \text { *** } \\
(-2.55)\end{array}$ & $\begin{array}{l}-0.294 \text { ** } \\
(-2.29)\end{array}$ & & & & \\
\hline QUINT_CEO_APPR & - & & & & & $\begin{array}{l}-0.038 \text { ** } \\
(-2.25)\end{array}$ & $\begin{array}{l}-0.035 \text { ***} \\
(-3.24)\end{array}$ & & \\
\hline CEO_APPR & - & & & & & & & $\begin{array}{l}-0.354 \text { ** } \\
(-1.92)\end{array}$ & $\begin{array}{l}-0.277 \text { * } \\
(-1.59)\end{array}$ \\
\hline INSIDER & ? & $\begin{array}{l}-0.005 \\
(-0.17)\end{array}$ & $\begin{array}{c}0.001 \\
(0.04)\end{array}$ & $\begin{array}{l}-0.211 \\
(-1.30)\end{array}$ & $\begin{array}{l}-0.192 \\
(-1.14)\end{array}$ & $\begin{array}{l}-0.062 \\
(-1.51)\end{array}$ & $\begin{array}{l}-0.068 \text { * } \\
(-1.97)\end{array}$ & $\begin{array}{l}-0.419 \\
(-2.16)\end{array}$ & $\begin{array}{l}-0.199 \\
(1.02)\end{array}$ \\
\hline$A P P R^{\star} I N S I D E R$ & + & $\begin{array}{c}0.007 \\
(0.54)\end{array}$ & $\begin{array}{l}-0.001 \\
(-0.07)\end{array}$ & $\begin{array}{l}0.231 \text { * } \\
(1.31)\end{array}$ & $\begin{array}{c}0.198 \\
(1.10)\end{array}$ & $\begin{array}{l}0.033 \text { ** } \\
(1.90)\end{array}$ & $\begin{array}{l}0.029 * \star * \\
(2.44)\end{array}$ & $\begin{array}{l}0.463 \text { ** } \\
(2.07)\end{array}$ & $\begin{array}{c}0.206 \\
(0.97)\end{array}$ \\
\hline CONTROLS & & NO & YES & NO & YES & NO & YES & NO & YES \\
\hline $\mathrm{R}^{2}$ & & 0.024 & 0.096 & 0.052 & 0.148 & 0.095 & 0.286 & 0.079 & 0.316 \\
\hline \# of obs & & 167 & 167 & 167 & 167 & 82 & 82 & 82 & 82 \\
\hline \# of insiders & & 116 & 116 & 116 & 116 & 56 & 56 & 56 & 56 \\
\hline
\end{tabular}


Table 5

CEO Turnover

This table reports coefficients and, in parentheses, related Wald Chi-square statistics for binomial logistic regressions. In Panel A the dependent variable indicates zero for the 1,442 (797) firm-year observations cases indicating either no CEO turnover or an unforced turnover, and one for the 55 (30) forced CEO turnovers. In Panel B the dependent variable indicates zero for the 1,469 (813) firm-year observations where there was no forced turnover with succession by an outsider and one for the 28 (14) with forced CEO turnovers with outside succession. Each panel reports the results for three different test variables based upon both board and CEO approval. BRD_APPR (CEO_APPR) is the median ratio of "for" votes to total votes cast across board members standing for election (CEO up for election) within a firm-year. QUINT APPR is the quintile rank of APPR from lowest to highest within each of the five years of the sample period. BQ1 (CQ1) equals 1 if the board (CEO) approval measure falls within the lowest quintile of $A P P R$ during the respective year, and 0 otherwise. AGE is the CEO's age at the shareholder meeting date. CONTROLS are performance measures (i.e., $R E T_{\mathrm{t}}, R E T_{\mathrm{t}-1}, R E T_{\mathrm{t}-2}, R O A_{\mathrm{t}}$ $R O A_{t-1}, R O A_{t-2}, C H G_{-} I N S T+O W N$ as previously defined in Table 3). We cluster by firm for all regressions and year fixed effects are included in the non-quintiled regressions. $\star \star \star *,{ }^{*}$, and ${ }^{*}$ indicate statistical significance at the $1 \%, 5 \%$ and $10 \%$ levels, respectively, in one-tail tests where the sign is predicted and in two-tail tests where the sign is not predicted.

\begin{tabular}{|c|c|c|c|c|c|c|c|}
\hline \multirow{2}{*}{$\begin{array}{l}\text { Explanatory variable } \\
\text { INTERCEPT }\end{array}$} & \multirow[t]{2}{*}{ Hyp. sign } & \multicolumn{3}{|c|}{$\begin{array}{c}\text { Prob. (1 = Forced Turnover) } \\
\text { (Board approval) }\end{array}$} & \multicolumn{3}{|c|}{$\begin{array}{c}\text { Prob. (1 = Forced Turnover) } \\
\text { (CEO approval) }\end{array}$} \\
\hline & & $\begin{array}{l}-2.904 \text { *** } \\
(6.01)\end{array}$ & $\begin{array}{l}3.350 \\
(2.08)\end{array}$ & $\begin{array}{l}-3.881 \text { *** } \\
(11.21)\end{array}$ & $\begin{array}{l}-2.622 * \\
(2.75)\end{array}$ & $\begin{array}{l}5.065 \\
(2.59)\end{array}$ & $\begin{array}{l}-3.963 * \star \star \\
(7.33)\end{array}$ \\
\hline QUINT_BRD_APPR & - & $\begin{array}{l}-0.260 \text { ** } \\
(5.34)\end{array}$ & & & & & \\
\hline BRD_APPR & - & & $\begin{array}{l}-6.442 * * \star \\
(9.69)\end{array}$ & & & & \\
\hline$B Q 1$ & + & & & $\begin{array}{l}0.853 * \star \\
(8.28)\end{array}$ & & & \\
\hline QUINT_CEO_APPR & - & & & & $\begin{array}{l}-0.434 \text { *** } \\
(7.50)\end{array}$ & & \\
\hline CEO_APPR & - & & & & & $\begin{array}{l}-8.890 * \star * \\
(11.06)\end{array}$ & \\
\hline CQ1 & + & & & & & & $\begin{array}{l}0.941 \text { ** } \\
(4.65)\end{array}$ \\
\hline$A G E$ & $?$ & $\begin{array}{l}0.006 \\
(0.09)\end{array}$ & $\begin{array}{l}0.005 \\
(0.05)\end{array}$ & $\begin{array}{l}0.007 \\
(0.12)\end{array}$ & $\begin{array}{l}0.010 \\
(0.14)\end{array}$ & $\begin{array}{l}0.017 \\
(0.43)\end{array}$ & $\begin{array}{l}0.009 \\
(0.12)\end{array}$ \\
\hline CONTROLS & & YES & YES & YES & YES & YES & YES \\
\hline Likelihood Ratio Chi Sq.Stat. & & 18.477 ** & 33.505 *** & 19.863 ** & 19.923 ** & 35.671 *** & 16.456 * \\
\hline Nagelkerke Psuedo $\mathrm{R}^{2}$ & & 0.045 & 0.082 & 0.049 & 0.089 & 0.158 & 0.074 \\
\hline \# of obs & & 1,497 & 1,497 & 1,497 & 827 & 827 & 827 \\
\hline \multicolumn{8}{|c|}{ PANEL B: Predicting forced turnovers with outsider replacement } \\
\hline Explanatory variable & Hyp. sign & Prob. (1 = Forc & $\begin{array}{l}\text { Irnover and Ou } \\
\text { 3oard approva }\end{array}$ & Replacement) & Prob. (1 = For & $\begin{array}{l}\text { Irnover and O } \\
\text { CEO approval }\end{array}$ & Replacement) \\
\hline INTERCEPT & & $\begin{array}{l}-2.337 \text { * } \\
(3.07)\end{array}$ & $\begin{array}{l}6.999 \\
(6.15)\end{array}$ & $\begin{array}{l}-4.005^{\star \star \star} \\
(7.42)\end{array}$ & $\begin{array}{r}-1.073 \\
(0.31)\end{array}$ & $\begin{array}{c}10.838 \text { *** } \\
(9.63)\end{array}$ & $\begin{array}{r}-3.124 \\
(2.34)\end{array}$ \\
\hline QUINT_BRD_APPR & - & $\begin{array}{l}-0.432 \text { *** } \\
(5.77)\end{array}$ & & & & & \\
\hline$B R D \_A P P R$ & - & & $\begin{array}{l}-9.750 * * * \\
(11.89)\end{array}$ & & & & \\
\hline BQ1 & + & & & $\begin{array}{l}1.279 * * * \\
(9.84)\end{array}$ & & & \\
\hline QUINT_CEO_APPR & - & & & & $\begin{array}{l}-0.670 \text { ** } \\
(10.37)\end{array}$ & & \\
\hline CEO_APPR & - & & & & & $\begin{array}{l}-13.105 \text { *** } \\
(13.98)\end{array}$ & \\
\hline CQ1 & + & & & & & & $\begin{array}{l}1.373^{\star \star \star} \\
(5.91)\end{array}$ \\
\hline$A G E$ & $?$ & $\begin{array}{r}-0.014 \\
(0.28)\end{array}$ & $\begin{array}{r}-0.018 \\
(0.47)\end{array}$ & $\begin{array}{r}-0.011 \\
(0.19)\end{array}$ & $\begin{array}{r}-0.028 \\
(0.64)\end{array}$ & $\begin{array}{r}-0.032 \\
(0.86)\end{array}$ & $\begin{array}{r}-0.028 \\
(0.62)\end{array}$ \\
\hline CONTROLS & & YES & YES & YES & YES & YES & YES \\
\hline Likelihood Ratio Chi Sq.Stat. & & 21.159 ** & $31.139 * \star *$ & 22.501 ** & 19.032 ** & 32.228 ** & 15.961 * \\
\hline Nagelkerke Psuedo $\mathrm{R}^{2}$ & & 0.083 & 0.121 & 0.088 & 0.144 & 0.242 & 0.121 \\
\hline \# of obs & & 1,497 & 1,497 & 1,497 & 827 & 827 & 827 \\
\hline
\end{tabular}


Table 6

\section{Director Turnover}

This table reports coefficients and, in parentheses, t-statistics for OLS regression models that explain director turnover, BRD_TURN, for the full sample of firms where director turnover is available and for a subsample that excludes CEO turnovers with outside successions. BRD_TURN is director turnover divided by the total number of board members standing for election. BRD_APPR is the median ratio of "for" votes to total votes cast across board members standing for election within a firm-year. QUINT_BRD_APPR is the quintile rank of BRD_APPR within each of the five years of the sample period. BQ1 equals 1 if the board approval measure falls within the lowest quintile of $A P P R$ during the respective year, and 0 otherwise. CONTROLS are performance measures (i.e., $R E T_{\mathrm{t}}, R E T_{\mathrm{t}-1}, R E T_{\mathrm{t}-2}, R O A_{\mathrm{t}}, R O A_{\mathrm{t}-1}, R O A_{\mathrm{t}-2}, C H G_{-} I N S T_{-} O W N$ as previously defined in Table 3). We cluster by firm for all regressions, and year fixed effects are included in the non-quintiled regressions. ${ }^{* * *},{ }^{* *}$, and * indicate statistical significance at the $1 \%, 5 \%$, and $10 \%$ levels, respectively, in one-tail tests where the sign is predicted and in two-tail tests where the sign is not predicted.

\begin{tabular}{|c|c|c|c|c|c|c|c|}
\hline \multirow{2}{*}{$\begin{array}{l}\text { Explanatory variable } \\
\text { INTERCEPT }\end{array}$} & \multirow{2}{*}{ Hyp. sign } & \multicolumn{3}{|c|}{$\begin{array}{c}\text { BRD_TURN } \\
\text { (including CEO turnovers with outside successions) }\end{array}$} & \multicolumn{3}{|c|}{$\begin{array}{c}\text { BRD_TURN } \\
\text { (excluding CEO turnovers with outside successions) }\end{array}$} \\
\hline & & $\begin{array}{l}0.305 * * * \\
(15.09)\end{array}$ & $\begin{array}{l}0.664 * * * \\
(3.78)\end{array}$ & $\begin{array}{l}0.228 * * * \\
(21.98)\end{array}$ & $\begin{array}{l}0.289 * * * \\
(14.75)\end{array}$ & $\begin{array}{l}0.597 * * * \\
(3.29)\end{array}$ & $\begin{array}{l}0.223 * * * \\
(21.73)\end{array}$ \\
\hline QUINT_BRD_APPR & - & $\begin{array}{l}-0.023 * * * \\
(-4.32)\end{array}$ & & & $\begin{array}{l}-0.022 * \star \star \\
(-4.02)\end{array}$ & & \\
\hline BRD_APPR & - & & $\begin{array}{l}-0.378 * * \\
(-2.15)\end{array}$ & & & $\begin{array}{l}-0.331 * \star \\
(-1.81)\end{array}$ & \\
\hline$B Q 1$ & + & & & $\begin{array}{l}0.056 * \star \star \\
(2.48)\end{array}$ & & & $\begin{array}{l}0.044^{* *} \\
(1.98)\end{array}$ \\
\hline CONTROLS & & YES & YES & YES & YES & YES & YES \\
\hline $\mathrm{R}^{2}$ & & 0.023 & 0.025 & 0.016 & 0.024 & 0.023 & 0.017 \\
\hline \# of obs & & 1,471 & 1,471 & 1,471 & 1,420 & 1,420 & 1,420 \\
\hline
\end{tabular}


Table 7

\section{Excess CEO Compensation}

This table reports coefficients and, in parentheses, t-statistics for OLS regression models that explain CEO excess compensation (in millions) during the first full fiscal year following an annual meeting. Excess compensation is estimated using the approach employed by Core, Guay, and Larcker (2008). The first three columns show results for models that contain board approval test variables and the second three columns show results for models that contain CEO approval test variables. BRD_APPR (CEO_APPR) is the median ratio of "for" votes to total votes cast across board members standing for election (CEO standing for election) within a firm-year. QUINT_BRD(CEO)_APPR is the quintile rank of $B R D(C E O) A P P R$ from lowest to highest within each of the five years of the sample period. BQ1 (CQ1) equals 1 if the board (CEO) approval measure falls within the lowest quintile of $A P P R$ during the respective year, and 0 otherwise. CONTROLS are performance measures (i.e., $R E T_{\mathrm{t}}, R E T_{\mathrm{t}-1}, R E T_{\mathrm{t}-2}, R O A_{\mathrm{t}}, R O A_{\mathrm{t}-1}, R O A_{\mathrm{t}-2}$, CHG_INST_OWN, as previously defined in Table 3). CONTRACT takes the value of one if the CEO has an explicit employment agreement and zero otherwise. We cluster by firm for all regressions and year fixed effects are included in the non-quintiled regressions. ***, **, and * indicate statistical significance at the $1 \%$, $5 \%$, and $10 \%$ levels, respectively, in one-tail tests where the sign is predicted and in two-tail tests where the sign is not predicted.

\begin{tabular}{|c|c|c|c|c|c|c|c|}
\hline \multirow{2}{*}{$\begin{array}{l}\text { Explanatory variable } \\
\text { INTERCEPT }\end{array}$} & \multirow[t]{2}{*}{ Hyp. sign } & \multicolumn{3}{|c|}{$\begin{array}{l}\text { CEO Excess Compensation } \\
\text { (Board Approval Measures) }\end{array}$} & \multicolumn{3}{|c|}{$\begin{array}{l}\text { CEO Excess Compensation } \\
\text { (CEO Approval Measures) }\end{array}$} \\
\hline & & $\begin{array}{l}-0.503 \\
(-0.54)\end{array}$ & $\begin{array}{l}-11.551 \\
(0.90)\end{array}$ & $\begin{array}{l}1.201 \\
(1.58)\end{array}$ & $\begin{array}{l}-1.219 \\
(-1.02)\end{array}$ & $\begin{array}{l}-38.478 * * * \\
(-2.90)\end{array}$ & $\begin{array}{l}2.209 * * \\
(2.34)\end{array}$ \\
\hline QUINT_BRD_APPR & + & $\begin{array}{l}0.452 \text { * } \\
(1.53)\end{array}$ & & & & & \\
\hline$B R D \_A P P R$ & + & & $\begin{array}{l}13.432 \\
(0.98)\end{array}$ & & & & \\
\hline$B Q 1$ & - & & & $\begin{array}{l}-1.959 * * \\
(-1.71)\end{array}$ & & & \\
\hline QUINT_CEO_APPR & + & & & & $\begin{array}{l}0.903 \text { ** } \\
(2.32)\end{array}$ & & \\
\hline CEO_APPR & + & & & & & $\begin{array}{l}42.319 * * * \\
(2.88)\end{array}$ & \\
\hline CQ1 & - & & & & & & $\begin{array}{l}-3.757 \text { *** } \\
(-2.85)\end{array}$ \\
\hline CONTRACT & $?$ & $\begin{array}{l}-0.346 \\
(-0.21)\end{array}$ & $\begin{array}{r}-17.184 \\
(-0.50)\end{array}$ & $\begin{array}{c}1.397 \\
(1.04)\end{array}$ & $\begin{array}{l}2.619 \\
(1.12)\end{array}$ & $\begin{array}{l}31.149 \\
(1.38)\end{array}$ & $\begin{array}{c}0.074 \\
(0.05)\end{array}$ \\
\hline$A P P R^{*} C O N T R A C T$ & $-1-1+$ & $\begin{array}{c}0.548 \\
(0.88)\end{array}$ & $\begin{array}{l}18.796 \\
(0.53)\end{array}$ & $\begin{array}{l}-1.193 \\
(-0.50)\end{array}$ & $\begin{array}{l}-0.594 \\
(-0.86)\end{array}$ & $\begin{array}{c}-31.298 \text { * } \\
(-1.33)\end{array}$ & $\begin{array}{l}3.205 \\
(1.25)\end{array}$ \\
\hline CONTROLS & & YES & YES & YES & YES & YES & YES \\
\hline $\mathrm{R}^{2}$ & & 0.024 & 0.096 & 0.052 & 0.048 & 0.063 & 0.049 \\
\hline \# of obs & & 330 & 330 & 330 & 203 & 203 & 203 \\
\hline \# of contracts & & 124 & 124 & 124 & 79 & 79 & 79 \\
\hline
\end{tabular}


Table 8

\section{Acquisition Activity}

The first three columns below report coefficients and, in parentheses, t-statistics for OLS regression models that explain cumulative 5-day returns surrounding acquisition announcements, ACQ_CAR. The second three columns report coefficients and, in parentheses, Wald Chi-Squared statistics for ordered logistic regression models that explain the number of acquisition announcements in the 12 months subsequent to the annual meeting, $A C Q \_F R E Q$. ACQ_CAR is estimated using CRSP-population data from a 255-day estimation period ending 46 days before the acquisition announcement for all acquisition announcements that took place in the 12 months subsequent to the annual meeting. ACQ_FREQ is the number of acquisitions that take place in the 12 months subsequent to the annual meeting. BRD_APPR is the median ratio of "for" votes to total votes cast across board members standing for election within a firm-year. QUINT_BRD_APPR is the quintile rank of $B R D \_A P P R$ within each of the five years of the sample period. $B Q 1$ equals 1 if the board approval measure falls within the lowest quintile of $A P P R$ during the respective year, and 0 otherwise. CONTROLS are performance measures (i.e., $R E T_{\mathrm{t}}, R E T_{\mathrm{t}-1}, R E T_{\mathrm{t}-2}, R O A_{\mathrm{t}}, R O A_{\mathrm{t}-1}, R O A_{\mathrm{t}-2}, C H G_{-} I N S T_{-} O W N$ as previously defined in Table 3 ). We cluster by firm for all regressions and year fixed effects are included in non-quintiled regressions. ${ }^{\star \star *}$, ${ }^{\star *}$, and * indicate statistical significance at the $1 \%$, $5 \%$, and $10 \%$ levels, respectively, in one-tail tests where the sign is predicted and in two-tail tests where the sign is not predicted.

\begin{tabular}{|c|c|c|c|c|c|c|c|c|}
\hline Explanatory variable & $\begin{array}{l}\text { Hyp. } \\
\text { sign }\end{array}$ & & ACQ_CAR & & $\begin{array}{l}\text { Hyp. } \\
\text { sign }\end{array}$ & & $A C Q \_F R E Q$ & \\
\hline INTERCEPT & & $\begin{array}{l}0.012 \text { * } \\
(1.89)\end{array}$ & $\begin{array}{l}0.085 \text { ** } \\
(2.00)\end{array}$ & $\begin{array}{r}0.000 \\
(-0.05)\end{array}$ & & - & - & - \\
\hline QUINT_BRD_APPR & - & $\begin{array}{l}-0.004 \text { ** } \\
(-2.04)\end{array}$ & & & + & $\begin{array}{l}0.061 \text { ** } \\
(2.13)\end{array}$ & & \\
\hline$B R D \_A P P R$ & - & & $\begin{array}{l}-0.085 \text { ** } \\
(-1.99)\end{array}$ & & + & & $\begin{array}{c}1.062 \\
(0.62)\end{array}$ & \\
\hline$B Q 1$ & + & & & $\begin{array}{l}0.010 \text { * } \\
(1.62)\end{array}$ & - & & & $\begin{array}{l}-0.250 \text { ** } \\
(2.77)\end{array}$ \\
\hline CONTROLS & & YES & YES & YES & & YES & YES & YES \\
\hline$R^{2}$ & & 0.024 & 0.023 & 0.016 & & & & \\
\hline Nagelkerke Psuedo $\mathrm{R}^{2}$ & & & & & & 0.031 & 0.040 & 0.032 \\
\hline Likelihood Ratio Chi Sq.Stat. & & & & & & $40.477 \star \star \star$ & $51.640 * \star \star$ & $41.101 * \star \star$ \\
\hline \# of obs & & 506 & 506 & 506 & & 1497 & 1497 & 1497 \\
\hline
\end{tabular}


Table 9

\section{Divestiture Activity}

The first three columns report coefficients and, in parentheses, t-statistics for OLS regression models that explain 5-day cumulative abnormal returns surrounding divestiture announcements, DIV_CAR. The second three columns report coefficients and, in parentheses, Wald Chi-Squared statistics for ordered logistic regression models that explain the number of divestiture announcements in the 12 months following the annual meeting, DIV_FREQ. DIV_CAR is estimated using CRSPpopulation data from a 255-day estimation period ending 46 days before the divestiture announcement for all divestiture announcement dates that took place in the 12 months subsequent to the annual meeting. BRD_APPR is the median ratio of "for" votes to total votes cast across board members standing for election within a firmyear. QUINT_BRD_APPR is the quintile rank of $B R D_{-}$APPR within each of the five years of the sample period. BQ1 equals 1 if the board approval measure falls within the lowest quintile of $A P P R$ during the respective year, and 0 otherwise. CONTROLS are performance measures (i.e., $R E T_{\mathrm{t}}, R E T_{\mathrm{t}-1}, R E T_{\mathrm{t}-2}, R O A_{\mathrm{t}}, R O A_{\mathrm{t}-1}$, $R O A_{t-2}, C H G_{-} I N S T \_O W N$ as previously defined in Table 3$)$. We cluster by firm for all regressions and year fixed effects are included in the non-quintiled regressions. ***, **, and * indicate statistical significance at the $1 \%, 5 \%$, and $10 \%$ levels, respectively, in one-tail tests where the sign is predicted and in two-tail tests where the sign is not predicted.

\begin{tabular}{|c|c|c|c|c|c|c|c|c|}
\hline Explanatory variable & $\begin{array}{l}\text { Hyp. } \\
\text { sign }\end{array}$ & & DIV_CAR & & $\begin{array}{l}\text { Hyp. } \\
\text { sign }\end{array}$ & & DIV_FREQ & \\
\hline INTERCEPT & & $\begin{array}{c}0.021 \\
(2.22)\end{array}$ & $\begin{array}{c}0.132 \\
(2.90)\end{array}$ & $\begin{array}{l}-0.001 \\
(-0.22)\end{array}$ & & - & - & - \\
\hline QUINT_BRD_APPR & - & $\begin{array}{l}-0.006 \text { *** } \\
(-2.41)\end{array}$ & & & - & $\begin{array}{l}-0.099 * * \\
(3.34)\end{array}$ & & \\
\hline BRD_APPR & - & & $\begin{array}{l}-0.119 * * * \\
(-2.70)\end{array}$ & & - & & $\begin{array}{l}-1.974 \text { * } \\
(1.55)\end{array}$ & \\
\hline$B Q 1$ & + & & & $\begin{array}{l}0.021 \text { *** } \\
(2.45)\end{array}$ & + & & & $\begin{array}{l}0.299 \text { ** } \\
(3.00)\end{array}$ \\
\hline CONTROLS & & YES & YES & YES & & YES & YES & YES \\
\hline$R^{2}$ & & 0.046 & 0.032 & 0.043 & & & & \\
\hline Nagelkerke Psuedo $\mathrm{R}^{2}$ & & & & & & 0.026 & 0.026 & 0.025 \\
\hline Likelihood Ratio Chi Sq.Stat. & & & & & & $28.745 * \star *$ & $28.061 * \star \star$ & $27.932 * \star \star$ \\
\hline \# of obs & & 275 & 275 & 275 & & 1497 & 1497 & 1497 \\
\hline
\end{tabular}

